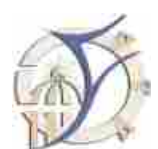

Fayoum University

\title{
THE OTTOMAN BEDESTENS IN GREECE
}

\author{
Ahmed AMEEN \\ Fayoum University, Egypt \\ ahmed.ameen@fayoum.edu.eg
}

\begin{abstract}
This paper focuses on the Ottoman bedestens in Greece, by considering the analysis and interpretation of the related texts in the archives and historic references. Evliyâ Çelebi provides a wealth of data regarding the Ottoman bedestens, along with their functions, administrative system and staff. This information underlines that the bedestens were semi-official buildings and were subject to State control and management, reflecting its commercial and economic policy.

This paper discusses the importance of the bedesten as a new architectural creation in the centre of the Ottoman city, and its importance in reorganising and distinguishing the layout of the core of some significant Ottoman cities. As a result, the historic Ottoman cities could be classified into cities including a bedesten and others that didn't. The study shows the relation between the presence of the bedesten in a city and its commercial and economic value considering the city's site. This is obvious for cities located on main commercial roads. Along the Via Egnatia, there are cities which have bedestens in Greece. The Ottoman bedestens found in Greece were accounted for, focusing on the surviving examples.
\end{abstract}

The study concludes that the Ottoman bedesten flourished from architecture and function point of view during the years of Sultan Mehmed II (1451-1481). This study proves that the present-day bedesten in the city of Serres is not the original one described by Evliyâ Çelebi, but it is a later reconstruction. The bedesten of Larissa was also dated in the light of the waqf (vakif) document of the founder Hacı Ömer Bey, the son of Hacı Turhan to the years before $889 \mathrm{H} / 1484 \mathrm{CE}$.

\section{KEYWORDS}

Ottoman commercial architecture, Greece, Balkan, Islamic architecture, Serres, Larissa.

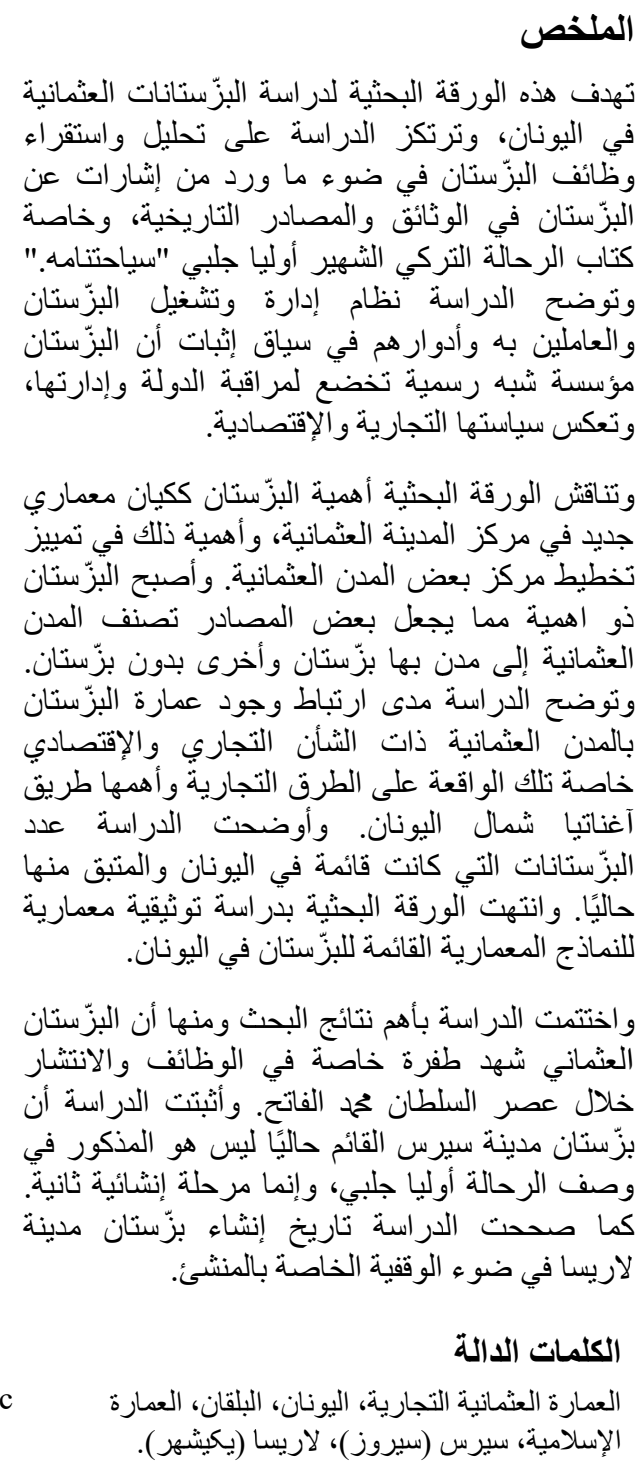




\section{INTRODUCTION}

Thousands of buildings were constructed under the Ottomans patronage in most areas of the territory of present-day Greece over a period ranging almost from three to five centuries. These architectural edifices gave an Ottoman flavour "Ottomanisation" to the skyline of Greek cities. The bedesten was one of the distinguished Ottoman commercial buildings in this regard. It was an Ottoman architectural creation; used mainly for trade and sale of fabrics and garments. There were also some additional functions in some bedestens. There were seven bedestens in Greece, from which three still exist. The main focus of this paper is documenting and reconsidering the foundation date of the Ottoman bedestens in Greece. It is also aims to analysing these structures in relation to the economic contexts including trade routes, goods, functions...

Previous studies that have dealt with the Ottoman bedestens in general such as the valuable study of M. Cezar "Typical Commercial Buildings of the Ottoman Classical Period and the Ottoman Construction System," and those existed in Greece in particular including the papers of: Machiel Kiel - Lazaros Deriziotis, "The old

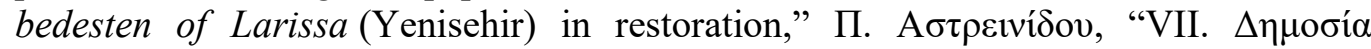

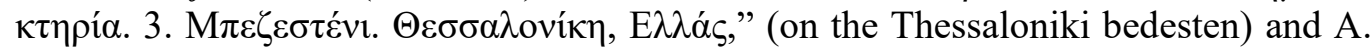

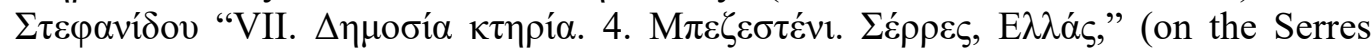
bedesten) were useful and essential to complete this study. But this paper is different in aim, methodology, and results. It focuses on the bedesten in Greece as a new foundation that ottomanised the centre of some Greek cities, and searches its influence on the Ottoman society. This paper analyse the demolished and the extant bedestens in Greece, based on the archival sources, travellers' works, previous studies, and the author's field work. From the architectural perspective, dating these buildings inscriptions is crucial. The paper suggests different dates for the surviving bedestens especially the Larissa bedesten.

This study may be extended in future research to include all the bedestens in the Balkans, or all commercial buildings in Greece and the Balkans. Such study can say more details on the economic and social life of Greece during the Ottoman centuries.

\section{OTTOMAN COMMERCIAL ARCHITECTURE IN GREECE}

Bazaar $^{1}$ (Tr: çarşı, or Souq in Arabic), khan (Tr. han), caravanserai (Tr. kervansaray), arasta, Bedesten (bezzâzistan) ${ }^{2}$ in addition to the small architectural units including

\footnotetext{
${ }^{1}$ As the core of the city, the bazar shows an urbanised composition rather than an architectural structure; it comprises the shops, streets, lanes. They are all related to the other buildings of the city. The site of the bazar was selected according to different criteria from one period to another. A central location and security were the most influential factors during the early and classic Ottoman periods. This explains the designation of early Ottoman mosques in the Balkans, as the Bazar Mosque (çarş1 cami') with the distinguished example the Fethiye Mosque in Athens. For details on the Fethiye Mosque in Athens see: Ameen, Islamic architecture in Greece: Mosques, 184.

${ }^{2}$ These different appellations of the Ottoman commercial architecture (khan, caravanserai, arasta, and bedesten) describe primarily structures of specific functions and architectural form. They are divided on whether they are located outside the city or within. This sorting depends also on the function, which determines in turn the architectural form. Yet it is noticeable that the significance of each appellation differed from one place to another, and even within the same place over centuries. For example, the khan in early Ottoman architecture was a commercial building outside the city on main trade roads almost the same as the caravanserai (see: Eryavuz, "Kervansaray," 299-302) or earlier Seljuk ribāt (see:
} 
shops (dukkan) and stores (makhzen), form the main commercial structures of the historic Ottoman city. These different names reflect variable functions, ${ }^{3}$ location, size, and characteristics of the architecture. Khan, ${ }^{4} \operatorname{arasta}^{5}$ and bedesten formed the key commercial buildings inside the Ottoman city. The bedesten, focus of this paper, is considered the most important commercial structure within the Ottoman city of the Balkans.

When we compare the amount of the extant Ottoman commercial buildings in Greece mentioned by Evliyâ Çelebi in 1660s and those at the end of the Ottoman rule over most of present-day Greece, it is important to consider their sites in relation to the trade and hajj routes (Figs. 2/3). This indicates the most flourishing cities, in terms of commerce, economy and urbanization, along these routes.

Via Egnatia is one of the most important trade routes along northern Greece (Fig. 1), which connects Istanbul and Edirne with Albania, then Italy. Figure 2 shows the increase of commercial buildings in the cities located along Via Egnatia or those nearby. They are Alexandroupoli "Dedeağaç", Xanthi "İskeçe", Serres "Siroz", Drama "Dirama", Kavala, Thessaloniki "Selânik", Veroia "Karaferye", Larissa "Yenişehir", Trikala "Tirhala" and Ioannina "Yanya". Seven Ottoman bedestens were built in Greece (Fig. 3, Table 1), five of which within cities located along Via Egnatia: Serres, Kavala, ${ }^{6}$ Thessaloniki, ${ }^{7}$ Veroia and Giannitsa "Yenice-i Vardar". The sixth bedesten is located in the city of Larissa somewhat close to Via Egnatia, and connects it with Peloponnese "Mora" and central Greece. The last bedesten was in Rhodes

Yiğit, "Ribât," 76-79; Elhaddad, Al-'ma'ra al-islamia fi Oroupa al-'Othmania, 260-261)- such as the Evrenos Bey khan in the Village of Ihca/Loutra in Greek Thrace (1370-1390) (see: Kiel, "The Oldest Monuments of Ottoman-Turkish Architecture in the Balkans," 133-138). But during the classic and late Ottoman periods, the Khan became the main commercial building inside cities, such as the khan ${ }^{2}$ of Gazi Husrev-beg in Sarajevo, Bosnia-Herzegovina (see: Hasab-Allah, 'ma'er Ghazi Khesro Bek albaqiyeh bimadinet Saraiavo, 249-257, Pls. 578-621). Evliyâ Çelebi mentioned tens of khans within the Ottoman cities of Greece in 1960s (see: Ameen, "The Ottoman architecture in Greece then and now," 101-106). Two centuries later in late $19^{\text {th }}$ century, the khan designated domestic buildings, providing rooms to rent for travellers. There is a significant surviving example, the khan of Georgos Anastasiou Kiretsi (Greek industrialist native of Naousa, was the first who established the industry of cotton ginning in in Naousa 1874-1875, and founded the extant Clock Tower "Saat Kulesi" at Naousa in 1311 Rumi/1895 CE. See: Ameen, "Bilingual and trilingual inscriptions of the Ottoman buildings," 23) at Thessaloniki. It was built in 1870, well preserved and hosts now the seat of the Epsilon movement (see:

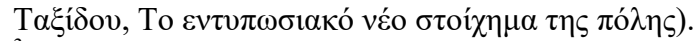

${ }^{3}$ The distinctions among these appellations and their associated architectural forms require careful examination, taking into account the place, time, and functional differences. The limited numbers of the Ottoman caravanserais compared to khans mentioned by Evliyâ Çelebi in the present-day Greece (see: Ameen, "The Ottoman architecture in Greece then and now," 101-106) refer to the fact that the caravanserais have their own specific functions, with different architectural details. This may explain the military defensive characteristics of the caravanserai architecture (see: Eryavuz, "Kervansaray," 299-301).

${ }^{4}$ There was a noticeable increase khan building within cities under the Ottoman rule during 15 th-17th centuries (See: Ameen, "The Ottoman architecture in Greece then and now," 101-106, 110). Hence, the khan was the most widespread commercial building.

5 Arasta, a Persian word which means to organise, refers to covered shopping streets (see: Çam, "Arasta," 335-336). It forms a mixture between the formation of the bazar and the bedesten. It came as a separate structure or attached to a group of buildings of the same founder, such as the arasta of Gazi Husrev-beg in Sarajevo (see: Hasab-Allah, 'ma'er Ghazi Khesro Bek al-baqiyeh bimadinet Saraiavo, 249-257, Pls. 578-621). As far as the author knows, there is no surviving arasta in Greece.

${ }^{6}$ Kiel, "Ottoman building activity along the Via Egnatia," 149-155.

${ }^{7}$ Delilbasi, "The Via Egnatia and Selânik," 67-84.

- 117 - The Ottoman bedestens in Greece 
Island, an important harbour in the Aegean Sea "Bahrisefid". It was a strategic stop along the maritime trade and hajj route Constantinople - Alexandria then to the Hejaz "al-Ḥijāz" and Silk route. ${ }^{8}$

According to Evliyâ Çelebi there were 3 caravanserais, 7 bedestens, and about 251 khans in Greece in 1660s. The limited number of caravanserais and bedestens suggests that they had distinct functions from the khans. The number of the Ottoman khans in Greece doubled after Evliyâ Çelebi's tally, reaching 571 khans in late $19^{\text {th }}$ century. ${ }^{9}$ This notable increase reflects the prosperity of commercial and economic activities, especially for cities such as Larissa (69 khans), Xanthi (63 khans), Ioannina (62 khans), Serres (44 khans). Thus, the increased number of khans in Thrace, Macedonia and Epirus mirrors a flourishing commerce, and in consequence urban growth. As far as the author knows, only three Ottoman khans survived; the oldest is the Evrenos Bey Khan ${ }^{10}$ in the Village of Loutra in Thrace (1370-1390) (Fig. 4), the second in Ioannina, and the third in Chania in Crete, from which only a portion of a wall exists.

Fig. 1. A map showing the Via Egnatia

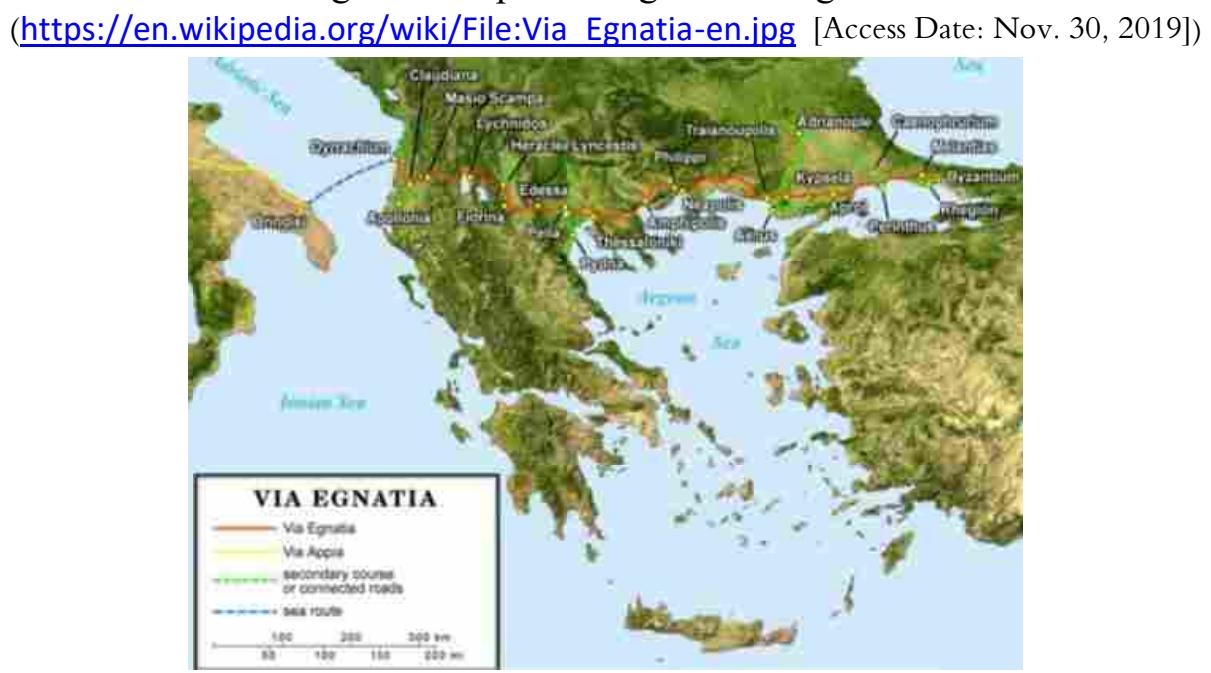

Fig. 2. Numbers of Ottoman khans and bedestens in Greece in the time of Evliyâ

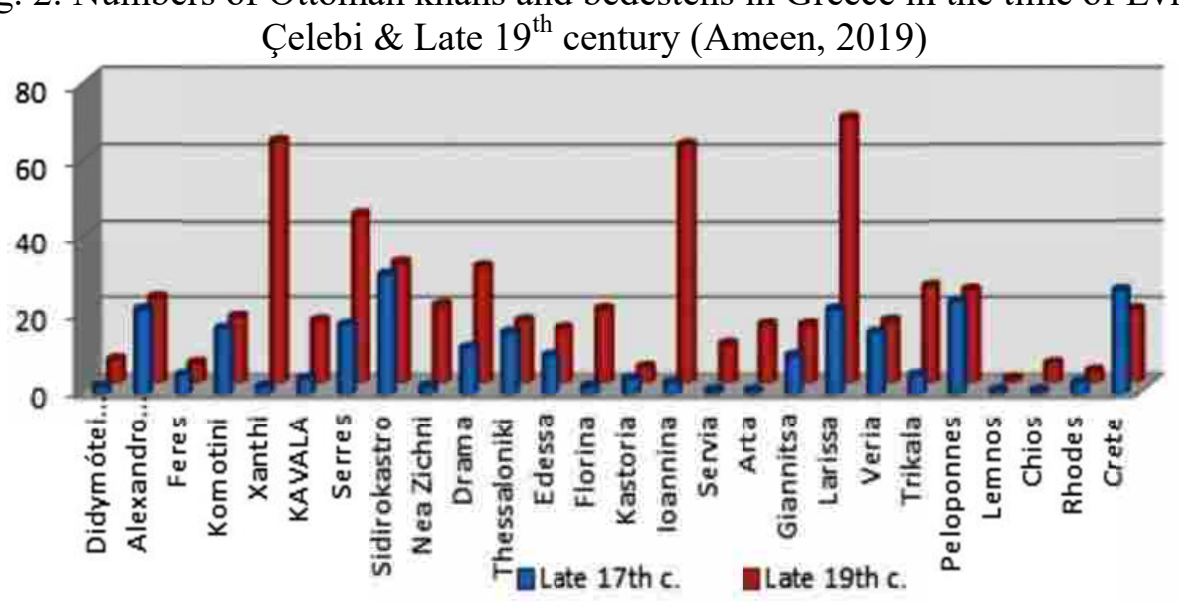

\footnotetext{
${ }^{8}$ Doğan, Fethinden Kaybına Rodos, 67-88, 72, 80.

9 Ameen, "The Ottoman architecture in Greece then and now," 101-106.

${ }^{10}$ Lowry, The Shaping of the Ottoman Balkans, 87-89, Pls. XXXII and XXXIII.
} 
Fig. 3. A map of Greece showing the cities and islands mentioned

(Source: https://www.map-of-greece.org/ [Access Date: Dec. 12, 2016]

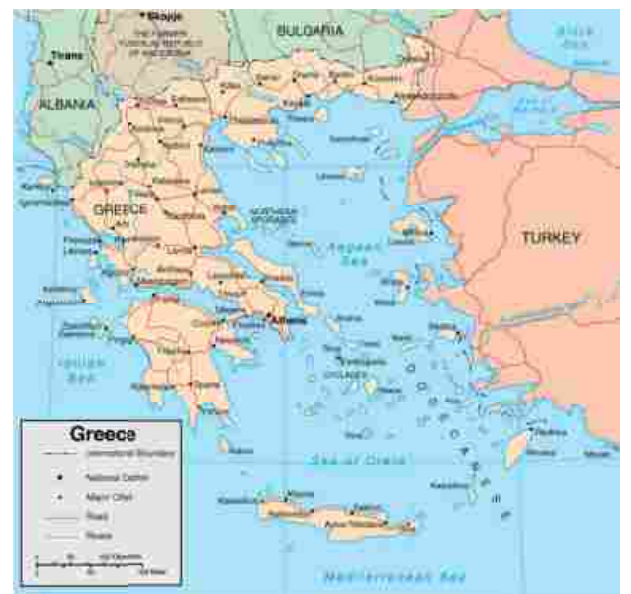

Fig. 4. The Evrenos Bey Khan in the Village of Loutra in Thrace: (A) the exterior, (b) the interior (Ameen, 2008)

B

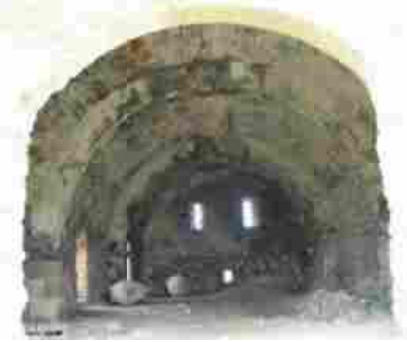

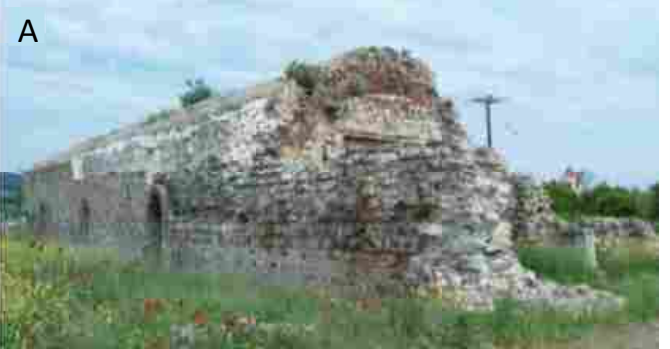

\section{THE OTTOMAN BEDESTENS IN GREECE}

Bedesten (Bezzistan; Bezzâzistan) is a compound word consisting of two syllables. The first is Arabic bezz "بّ", meaning fabrics and clothing, ${ }^{11}$ and the second part stan "ستان" is a Persian suffix denoting the place; the term means the place of trade and sale of fabrics and garments. The bedesten ${ }^{12}$ is a large rectangular hall covered with

\footnotetext{
${ }^{11}$ Bezz "بّ" means cloth, or household goods from clothing and the like, and its seller: al-Bazzāz, and his craft: al-Bezzāza. Also it means the weapon, like the military uniform, see: alfayrūzābādey, alqāmūs almuhịț, 503. Identifying the corresponding building and function in other parts of Islamic World provides interesting results. In Morocco, the term Kaysāriyya identifies a fenced bazar with doors closing at night, in which fabrics and types of jewellery were sold. Kaysāriyya in Marrakesh comprises shops selling fabrics only, while in Andalusia it also sold cloth, perfumes, and cosmetology. See: Streck, "Kaysāriyya”, 840-841.

12 Eyice, "Bedesten. Osmanlı dönemi Türk şehirlerinde ticaret," 302. While in the eastern Islamic world, khan and Kaysāriyya used to label such commercial building, and the term bedesten appeared occasionally in the Levant during Ottoman times, specifically in the second half of the 10th AH/16th century CE such as the old bedesten at Damascus (before 1002 AH/1593 CE) (see: Yahya, "An archaeological inventory of the Damascene khans", 86, no. 216) and the Muradiye bedesten (1005 AH/1596 CE) (see: Its description corresponds to Gümruk khan. Yahya, "An archaeological inventory of the Damascene khans”, 93. no. 221). The latter's waqfiyeh cited the architectural characteristics of the building: "It has four doors, divided into nine areas, covered with nine domes based on eight semicircular arches, and on the exterior, there are nine shops." The architecture of the Muradiye Khan, located western of the Umayyad Mosque, is completely different from the description mentioned in its waqfiyeh; its corresponds to the architecture of the bedesten. Because the latter was destroyed and the one existing now dates to the early 20th century (see: Al-Rīhāwī, "The Khans of Damascus," 62) This description corresponds with the architectural characteristics of the Ottoman bedesten. The gümürk khan, (see: Yahya, "An archaeological inventory of the Damascene khans", 62) close to the aforementioned Muradiye bedesten has almost the same description. Whilst, Evliyâ Çelebi did not mention the bedestens of Damascus, it is clear that they were built later than his visit in 1670s. On the other hand, Evliyâ Çelebi mentioned one bedesten in Aleppo, Baghdad, Tripoli (Lebanon), and Nablus.
}

- 119 - The Ottoman bedestens in Greece 
two rows of domes covered with lead, the walls being made of stones, or a mix of stones and bricks. The hall is frequently articulated by one storey of shops. The interior is divided into parallel square areas by massive central pillars. It formed the core of the bazar and of the whole city. There, the most valuable fabrics, precious commodities including silver, gold, and jewellery, were sold. In addition, money, important documents, and valuables were deposited in its midst. The bedesten is a direct evolution of Seljuk and Emirates' drapers' khans "خان البزَّازية" dedicated to the same function of fabrics' trade. However, the bedesten in terms of architecture and function is an Ottoman creation.

Evliyâ Çelebi drew a fascinating picture of life in the Ottoman Balkans in the second half of the $11^{\text {th }} \mathrm{AH} / 17^{\text {th }} \mathrm{CE}$ century, including the commerce and trade contexts. He sometimes characterised products with their local nicknames and prices, and described the bazar and commercial buildings of each city. He often mentioned the city bazar, its number of shops, the local guilds, famous professions, and industries. Regarding the commercial buildings, the merchants' khans are counted. Bedestens are referred to in this author's works linked to a neighbourhood, the bazar bedesten "Çarşısı bedesteni", or to the bedesten itself. The first is the bazar with its shops, up to thousands in some cities, concentrating the trade of different fabrics and other merchandises. The second is the focus of this paper, the bedesten building, which was usually the focal point of the bazar, surrounded by shops.

Evliyâ Çelebi has always described the bedesten as a massive stone structure, fortified, roofed with lead-covered domes, with iron gates. Sometimes, he adds that it contains the precious commodities in general, and those of fabrics and perfumes particularly, and its shops are full of goods, treasures and money.

Evliyâ Çelebi listed, in the $5^{\text {th }}, 8^{\text {th }}$ and $9^{\text {th }}$ volumes of his work Seyahatname, thirtyone cities and islands within present-day Greece. ${ }^{13}$ Among these, seven included a bedesten. ${ }^{14}$ Its absence is confirmed in the other twenty four cases (Table 1). ${ }^{15}$ Evliyâ nevertheless argued almost that the excellent and precious goods, finest clothing and textiles were available despite the absence of the bedesten. This reflects the correlation made between the availability of quality goods and the bedesten at his time.

Moreover, he confirmed the presence of three bedestens in each of Safed (Palestine) and Medina (The Arabian Peninsula) (see: Cezar, Typical Commercial Buildings, p. 167). In Egypt there were one bedesten in Alexandria (see: Evliyâ \#7, p. 360) and two in Rosetta (Raşid) (see: Evliyâ \#7, p. 374). He also mentioned one bedesten in the cities of Gence (or Ganja) in Azerbaijan, Qazvin and Tabriz in Iran (see: Cezar, Typical Commercial Buildings, p. 167).

${ }^{13}$ Evliyâ \#1; Evliyâ \#2; Evliyâ \#3; Evliyâ \#4; Evliyâ \#5; Evliyâ \#6.

${ }^{14}$ Cezar states that there were five bedestens in Greece according to Evliyâ Çelebi, comprising those of Thessaloniki, Giannitsa, Veria, Serres and Larissa, but did not refer to the bedestens of Kavala and Rhodes. Cezar, Typical Commercial Buildings, 16.

${ }^{15}$ Evliyâ cited, among many examples, his description of the bazar of the cities of Didymóteichon (Evliyâ \#5, 8, 72) and Genisea (Evliyâ \#5, 8, 110), which emphasised that despite the nonexistence of a bedesten, the bazar was full with amazing and rare goods. The same was repeated for the Komotini bazar, where he wrote: "Although there is no bedesten, excellent merchandises from the seven regions of the world are found and available, and are easy to obtain." (Evliyâ \#5, 8, 85) In the case of Trikala, he said: "As for the bedesten, there is no found; but all artifacts of the world are available in this city." (Evliyâ \#5, 8, 203) In Athens, he said: "As for the bedesten, there is none to be found; but all magnificent dresses and rare clothes are existing in the bazar."( Evliyâ \#5, 8, 254) In the case of Ioannina, Evliyâ argued the availability of the best quality clothes and commodities, though the absence of the bedesten, and said: "the bedesten is not found, but the finest Frankish clothing is present in this city thanks to the close Greek island of Corfu, six hours away." (Evliyâ \#5, 8, 630, 637). 
Table 1: The bedestens in Greece in the time of Evliyâ Çelebi and now (Ameen, 2020)

\begin{tabular}{|c|c|c|c|c|c|c|c|}
\hline \multirow{2}{*}{ Ser. } & \multicolumn{3}{|c|}{ TOPONYMES } & \multicolumn{2}{|c|}{$\begin{array}{c}\text { Existence of } \\
\text { bedesten }\end{array}$} & \multirow{2}{*}{$\begin{array}{c}\text { Evliyâ's } \\
\text { Description }\end{array}$} & \multirow{2}{*}{$\begin{array}{c}\text { Current } \\
\text { State/Functi } \\
\text { on }\end{array}$} \\
\hline & تثماني/Ottoman & Greek / English & Arabic & Evliyâ & Now & & \\
\hline 1 & ديمتوقه، ديديموتيخوس/Dimetoka & $\Delta ı \delta v \mu o ́ \tau \varepsilon \imath \chi_{0} /$ Didymóteichon & ذيذيموتيخو & $\mathrm{No}^{16}$ & - & - & - \\
\hline 2 & Gümülcine/ كومُلجنه & 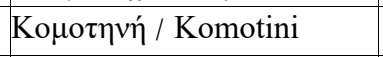 & كوموتنين & No & - & - & - \\
\hline 3 & يكيهء قره صو/ Yenice-i Karasu & 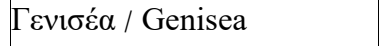 & ينيسيا & No & - & - & - \\
\hline 4 & Kavala / قواله & K $\alpha \beta \alpha ́ \lambda \alpha$ / Kavala & كاقلا & Yes & No & - & - \\
\hline 5 & Dirama / درامه، ديرامه & $\Delta \rho \alpha ́ \mu \alpha$ / Drama & ذراما & No & - & - & - \\
\hline 6 & زيخنه / Zihne & 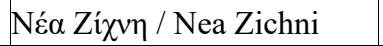 & نيا زيخني & No & - & - & - \\
\hline 7 & Siroz / كيروز & $\sum \varepsilon \dot{\varepsilon} \rho \rho \varepsilon \varsigma /$ Serres \& Serrai & 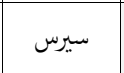 & Yes & Yes & Different & $\begin{array}{l}\text { Good/ } \\
\text { Museum }\end{array}$ \\
\hline 8 & سلانيك / Selânik & 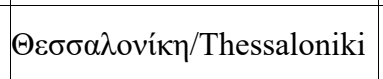 & 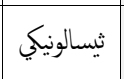 & Yes & Yes & The same & $\begin{array}{c}\text { Good/ } \\
\text { The same }\end{array}$ \\
\hline 9 & كيبه، يكيجه، واردار/ Yenice-i Vardar & 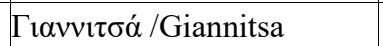 & يانيتسا & Yes & No & - & - \\
\hline 10 & وودينه، ثودينه، آدسّه/Vodina & E $\delta \varepsilon \sigma \sigma \alpha /$ Edessa & إِدسا & No & - & - & - \\
\hline 11 & |قره فريه/Karaferye & 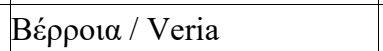 & ثيريا & Yes & No & - & - \\
\hline 12 & يكيشهر / Yenişehir, Yenişehir-1 Fenar. & $\Lambda \alpha ́ \rho ı \sigma \alpha /$ Larissa & 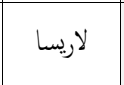 & Yes & Yes & Different & $\begin{array}{c}\text { Semi } \\
\text { ruined }\end{array}$ \\
\hline 13 & Tirhala/a ترحاله & Tрíк $\alpha \lambda \alpha$ / Trikala & تريكالا & No & - & - & - \\
\hline 14 & أزدين، زيتون، لاميا/İzdin & $\Lambda \alpha \mu i ́ \alpha$ / Lamia & 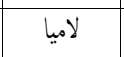 & No & - & - & - \\
\hline 15 & Eğriboz, Ağriboz/آغريبوز & X $\alpha \lambda \kappa i ́ \delta \alpha /$ Eubee, Boeotia, Chalkida & خالكيذا & No & - & - & - \\
\hline 16 & Atina/ آننه & A $\theta \dot{v} v \alpha$ / Athenes, Athens & أثنينا & No & - & - & - \\
\hline 17 & آنابولى Anabolu & Nav́ $\pi \lambda$ เo/ Navplion, Nafplio & نافبليو & No & - & - & - \\
\hline 18 & سالونه / Salona & A $\mu \varphi ı \sigma \sigma \alpha /$ Amfissa, Saline, Salna & أمفيسا & No & - & - & - \\
\hline 19 & كربنيش/Kerbeneş & 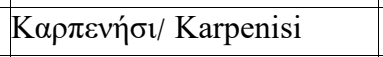 & كاربنيسي & No & - & - & - \\
\hline 20 & اينه بنتى/İnebahti & 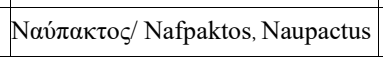 & نافبكتوس & No & - & - & - \\
\hline 21 & فير اهور/Virahor & A $\gamma \rho$ ívio/ Agrinio, Vrachori & آغرينيو & No & - & - & - \\
\hline 22 & Narda/نارده & A $\rho \tau \alpha /$ Arta & آرتا & No & - & - & - \\
\hline 23 & بانيه/Yanya & 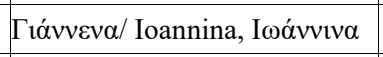 & يانيننا & No & - & - & - \\
\hline 24 & آيدونات، ياراميتى/Aydonat & П $\alpha \rho \mu v \theta i \alpha$ / Paramithia & باراميثيا & No & - & - & - \\
\hline 25 & دلوينه/Delvinye & $\Delta \varepsilon \lambda \beta ı$ ó́кı/ Delvinaki, Devline & دياثشينكى & No & - & - & - \\
\hline 26 & ساقز ، صاقز / Sakiz & Xíos / Chios & خيوس & $\mathrm{No}^{17}$ & - & - & - \\
\hline 27 & استانكوى/İstanköy & 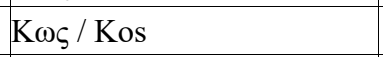 & S & No & - & - & - \\
\hline 28 & ماروس/Rodos & 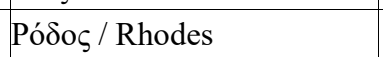 & 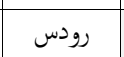 & Yes & No & - & - \\
\hline 29 & فيلورينه، فلورينه/Florine & $\Phi \lambda \omega ́ \rho ı v \alpha$ / Florina & فلورينا & $\mathrm{No}^{18}$ & - & - & - \\
\hline 30 & كesriye/كسيه & 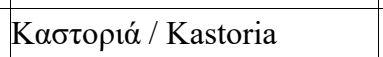 & كاستوريا & No & - & - & - \\
\hline 31 & سرفيجه/Serfiçe & $\sum \varepsilon ́ \rho \beta 1 \alpha /$ Servia & صرثيا & No & - & - & - \\
\hline
\end{tabular}

\footnotetext{
${ }^{16}$ The cities and sites listed in the table numbers 1: 25 are listed in the 8th volume of Evliyâ Çelebi in the following order: Evliyâ \#5: p. 72, 85, 110, 115, 119, 123, 129, 158, 168, 175, 179, 192, 203, 217, $238,254,560,587,588,591,604,620,630,637,644$.

${ }^{17}$ The islands Chios, Kos and Rhodes listed in the table, numbers 26: 28 are listed in the $9^{\text {th }}$ volume of Evliyâ Çelebi in the following order: Evliyâ \#6: 133, 241, 275.

${ }^{18}$ The cities Florina, Kastoria and Servia listed in the table, numbers 29: 31 are listed in the $5^{\text {th }}$ volume of Evliyâ Çelebi in the following order: Evliyâ \#4: 800, 802, 812.
} 
According to Evliyâ Çelebi, as stated earlier, there were seven bedesten in Greece, including those located in Serres, Thessaloniki and Larissa, almost in ruins. The details Evliyâ mentioned about the vanished bedestens confirm that they were close replicas of the surviving ones. He described the bedesten of Giannitsa ${ }^{19}$ as " $a$ massive fortified stone building roofed with six lead-covered domes with four iron gates, and there is no place comparable to its magnificence in the city. ${ }^{, 20}$ Regarding the Veroia bedesten, he identified it among the waqf buildings of Çelebi Sinan, and its description shows the high similarity with the Giannitsa bedesten. ${ }^{21} \mathrm{He}$ also mentioned that the bedesten of Kavala belonged to Ibrahim Pasha. ${ }^{22}$

The three bedestens which were preserved are the focus, and are considered through the data of the waqfiyehs and the historical sources, especially Evliyâ Çelebi, as well as their present state according to our visits in 2008, 2014, and 2016.

\section{THE SERRES “SIROZ” BEDESTEN}

Despite the many modifications that were carried out in the Serres bedesten, which changed its original form, it is still considered one of the most important architectural examples of the bedestens in the Balkans. During Ottoman times, Serres ${ }^{23}$ was one of the most important cities in the Rumeli from several aspects, whether historical, cultural, economic, or architectural, and it was one of the few cities included earlier mint (darbhâne). ${ }^{24}$ In addition to the mint and the bedesten, there were two caravanserais, 32 khans and a bazar with more than 2000 shops "dukkān". This clearly reflects the commercial and economic importance of the city at that time. Its strategic location, on the Egnatia route, ${ }^{25}$ in the centre of Macedonia and Thrace, the core of Rumeli, and close to the sea and Edirne, increased its commercial importance. The bedesten itself is located on the western side of eleftheria square, the central square of the city since Ottoman times. Then it faced the western side of the Old Mosque, on the main bazar street. ${ }^{26}$

The certain foundation date of the bedesten is unknown. The oldest known reference mentioning the Serres bedesten is the waqfiyeh of Ibrahim Paşa, ${ }^{27}$ son of Grand Vizier Kara Halil Çandarli, dated to mid Rajab 899 AH/April 1494 CE. This waqfiyeh stated that the annual revenue of the Serres bedesten along with its interior shops was 6708 $a k c ̧ e$, and that of the exterior shops was 3420 akçe. The same waqfiyeh ${ }^{28}$ mentioned among its payments a specific sum for collection of the revenues of the Serres

\footnotetext{
19 It was stood on the Paleo Pazarou in the lower part of the town, and it was still in existence even in ruins before World War II. See: Kiel, "Yenice-i Vardar (Vardar Yenicesi Giannitsa),” 307, 318, 329a, n. At p. 318.

${ }^{20}$ Evliyâ \#3, p. 77.; Evliyâ \#5, 8, 168.

${ }^{21}$ Evliyâ \#3, p. 72.; Evliyâ \#5, 8, 179.

22 Evliyâ \#5, 8, 115.

${ }^{23}$ Şemseddin, Kamûs-ül Â'lâm, vol. 4, 2755-2756.

${ }^{24}$ Lowry, The Shaping of the Ottoman Balkans, 177.

${ }^{25}$ Evliyâ \#5, 8, 126-129; Selanik Vilayeti Salnâmesi 1325, 340; Ayverdi, Avrupa'da Osmanli Mimari Eserleri, IV., 291-302; Kiel, "Observations on the History of Northern Greece", 429-444.

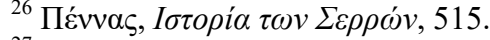

${ }^{27}$ Gökbilgin, XV - XVI Asirlarda Edirne Ve Paşa Livasi, 424-426.

${ }^{28}$ Gökbilgin, XV - XVI Asirlarda Edirne Ve Paşa Livasi, 425.
} 
bedesten. Kara Halil Çandarli ${ }^{29}$ was the conqueror of Serres -with the Ghazi Evrenos Bey-, he constructed many buildings in Serres, and endowed many lands and possessions as a waqf.

Akozan attributed the Serres bedesten to Halil Paşa Çandarli, ${ }^{30}$ and suggests the Eski Mosque date $(787 \mathrm{AH} / 1385 \mathrm{CE})^{31}$ as its own foundation date. Considering the abovementioned waqfiyeh the founder of the bedesten is Ibrahim Paşa (1429-1499 CE) son of Halil Paşa Çandarli, and the foundation date would be before $899 \mathrm{AH}$ (April $1494 \mathrm{CE})^{32}$

I propose that the original bedesten of Serres described by Evliyâ Çelebi was constructed in the mid- $9^{\text {th }} \mathrm{AH} / 15^{\text {th }} \mathrm{CE}$ century; considering the similarity of the architectural characteristics of the original bedesten of Serres described by Evliyâ with the bedestens of Sandal and Galata ${ }^{33}$ in Istanbul attributed to the Fatih Sultan Mehmed, as well as the Tokat bedesten ${ }^{34}$ (mid $9^{\text {th }} \mathrm{AH} / 15^{\text {th }}$ century CE), and the demolished bedesten of Konya. ${ }^{35}$

The present standing bedesten is rather different from the original one described by Evliyâ Çelebi: " a bedesten roofed with nine lead-covered domes, has four iron gates, and encloses the shops of the rich merchants." number of domes, with only six on the standing bedesten. Thus, the now standing building is a reconstruction and not the old original bedesten. This reconstruction was likely done along with the reconstruction of the Eski Mosque which was facing the bedesten after the 1719 big fire, perhaps after the front suffered from the fire as well. ${ }^{37}$ The Çandarli family is recommended as the patron of the reconstruction of both the Eski Mosque and the bedesten. Moreover, the Serres bedesten suffered from fires in $1630,1638,1714,1718$ and $1894 .{ }^{38}$ The last fire caused the disappearance of the exterior shops of the reconstructed bedesten. The bedesten has been restored in $1938 .{ }^{39}$ This restoration included the replacement of exterior covering of the domes with tiles -according to the Byzantine Greek School (Fig. 7)- instead of the original lead sheets.

\footnotetext{
${ }^{29}$ Aktepe, "Çandarli. XIV,” 209-211.

${ }^{30}$ Akozan, "İstanbul'un Kapalı Çarşısı," 763.

31 The Eski Mosque of Serres was his most important building, though it was destroyed in the great fire of 1719, and its original foundation inscription lost during its reconstruction. Fortunately, Evliyâ Çelebi recorded the content of its original Arabic foundation inscription, which cited the foundation date 787 $\mathrm{AH} / 1385 \mathrm{CE}$, and the founder's name Halil bin Ali al-Çandarli. This reconstructed version then existed until it was destroyed in World War I. See: Kiel, "Observations on the History of Northern Greece," 432.

${ }^{32}$ Gökbilgin, XV - XVI Asirlarda Edirne Ve Paşa Livasi, 423-426.

${ }^{33}$ About the bedestens of Istanbul see: Malaka, Al-monsha'āt al-tugāriyeh al-' othmāniyeh, 79-93.

${ }^{34}$ Cezar, Typical Commercial Buildings, 178-183, 215.

35 Baş - Bozkurt, "Konya Bedesteni," 493-506.

36 Evliyâ \#5, 8, 129.

${ }^{37}$ Kiel, "Observations on the History of Northern Greece," 431-432.

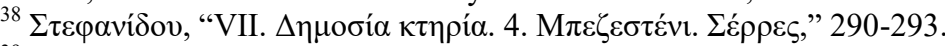

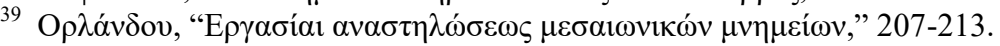


Fig. 5. A plan of the Serres Bedesten, ground floor level (Ameen, 2016)

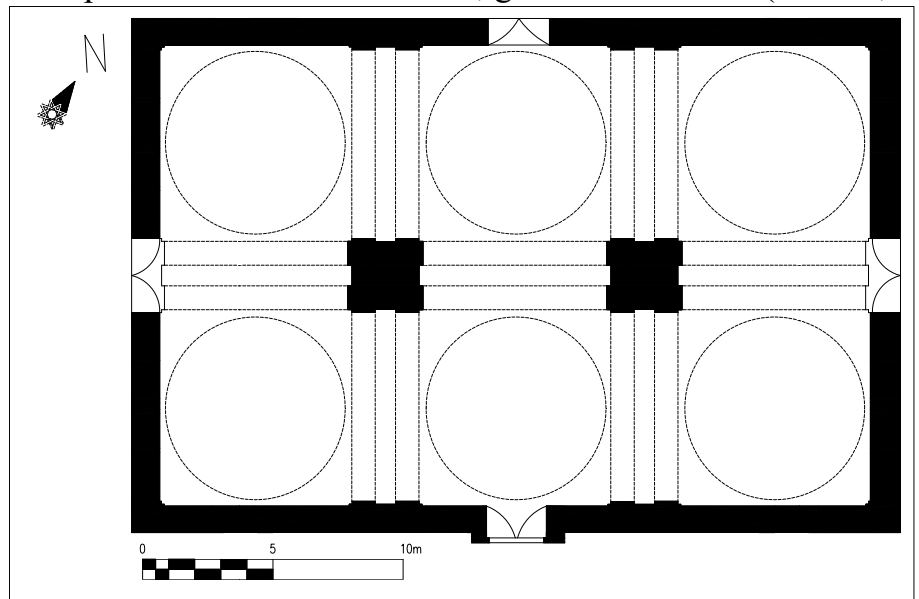

Fig. 6. Interior elevations of the Serres Bedesten, (A) the longitudinal side (B) the transversal

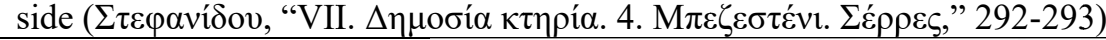

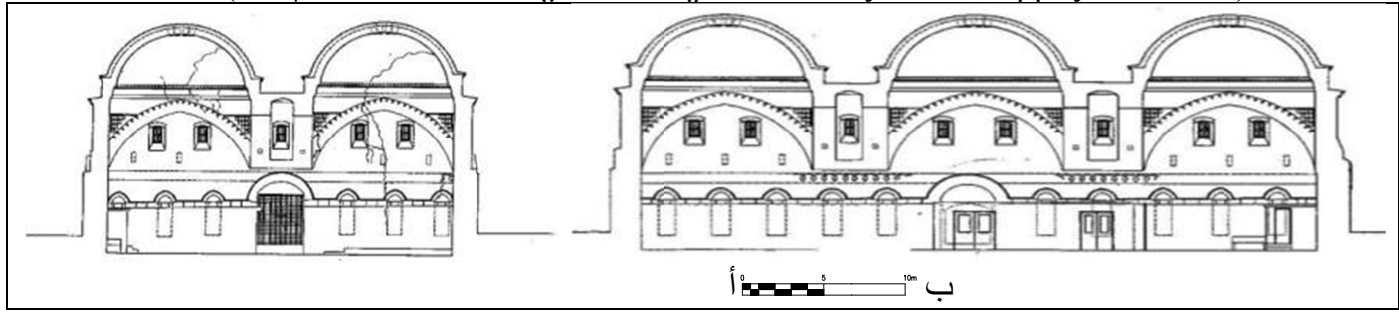

The Serres bedesten continued with its original functions until $1913 \mathrm{CE}$, when the Bulgarians occupied the city during the First Balkan War (October 1912 to May 1913). The structure was then used as military barracks during World War I. It suffered many misuses after the World War II until 1962, when it was recorded as a historic building belonging to the Greek Ministry of Culture. The building was under a project of restoration between 1962-1968, aiming to its reuse as the Archaeological Museum of the city of Serres since 1970, a function which it still fulfils. The present good condition of the bedesten is owed to a series of restoration and preservation works done during the $20^{\text {th }}$ century. ${ }^{40}$

\section{The Serres bedesten architecture}

The bedesten is a free-standing building with four façades and four axial doors. It consists in its present state of a rectangular plan measuring 20.60 by 31.45 metres, including the walls (Fig. 5), which are almost 14 metres high. The thickness of the walls ranges from 0.90 metre to 1.40 metres, since it decreases gradually with heightened elevation. It is covered with six parallel hemispherical blind domes resting on octagonal drums carried by seven double arches supported by two central massive piers ( $3.17 \times 3.28$ metres) and the walls.

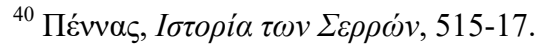


Fig. 7. The Serres Bedesten, Above general view showing the roof and SE and SW facades ${ }^{41}$

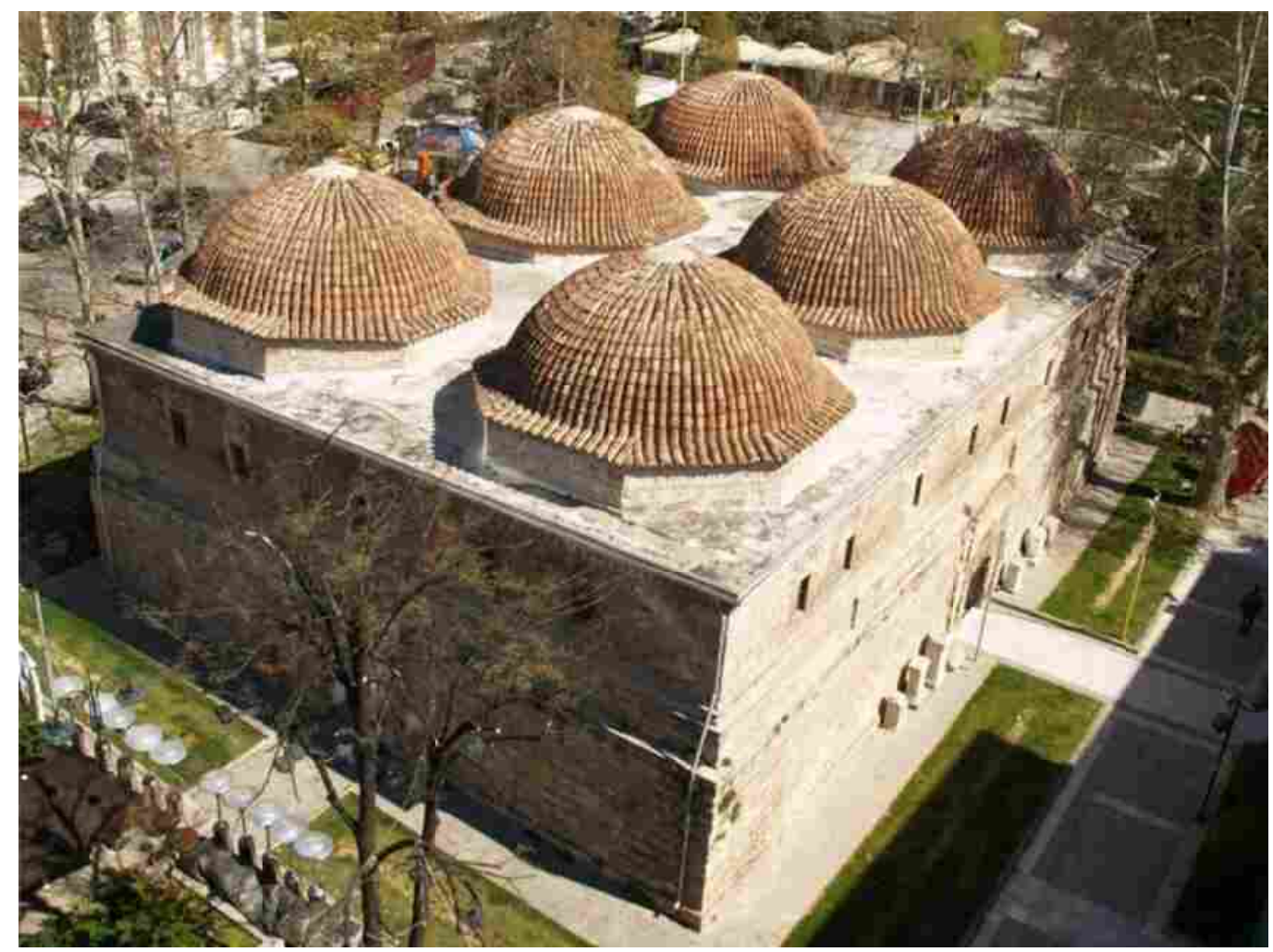

The facades up to 5 metres high reflect the many modifications made to this building as a result of fires, its misuse during the period 1913-1962, and the frequent restoration works. The lower tier of windows, large rectangular windows characteristic of Ottoman buildings, is not seen in this bedesten. The facades often up to 5 metres, were occupied by external shops. Moreover, this kind of windows is inconsistent with the main purpose of the bedesten of being a well-protected and secured building. These windows date thus of modifications after 1913, after it lost its original function, and they were all walled in 1938 (Fig. 7). ${ }^{42}$

A horizontal podium at a height of 5 metres runs along the facades, forming the support on which the roof of external shops rested (Fig. 7). These shops burnt completely and vanished. The facades, up to this point, are built with rubble, inset pieces of brick, whereas the corners, lintels, and arches are built with large blocks of hewn stone. The upper masonry is built in cloisonné ${ }^{43}$ style according to the Byzantine Helladic School (Fig. 8), in which bricks are frequently positioned vertically, and each stone piece is surrounded by brick on four sides. There is an upper tier of 26 small arched windows inset with iron grills, and 8 windows in each longitudinal side and 5 windows for each transversal side are equally distributed. These windows enable natural light inside the bedesten (Fig. 8, 11).

${ }^{41}$ Plates of the bedestens in Greece included here are of the author in 2008.

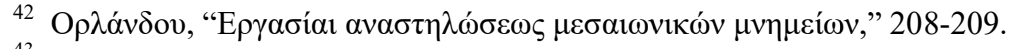

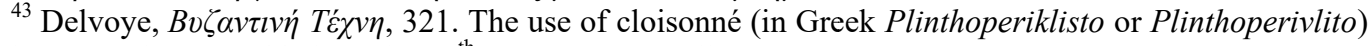
began in the second half of the $10^{\text {th }}$ century, see: Millet, L'école grecque dans l'architecture byzantine, 225-226; Krautheimer, Early Christian and Byzantine Architecture, 402-403.

- 125 - The Ottoman bedestens in Greece 
Fig. 8. The Serres Bedesten, a detail of the upper part of the SE façade

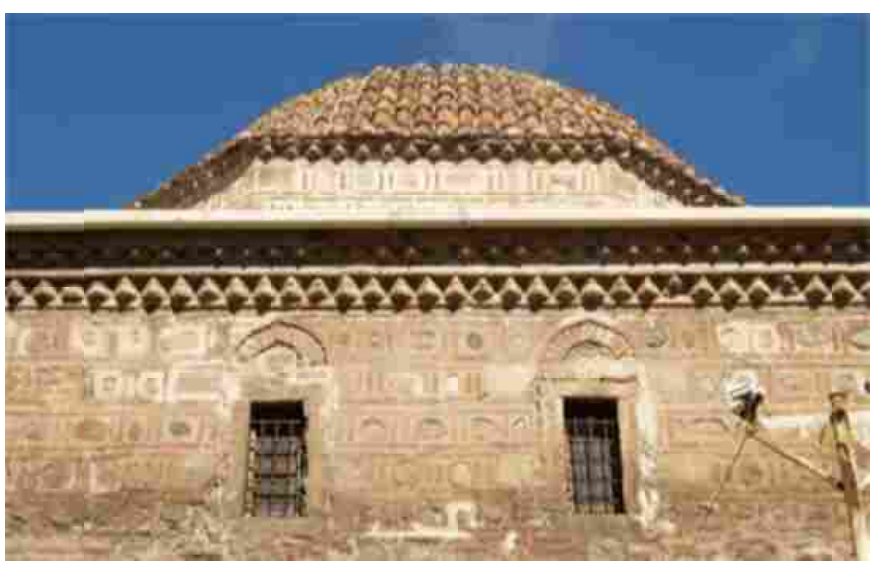

Fig. 9. The Serres Bedesten, the middle part of the SE

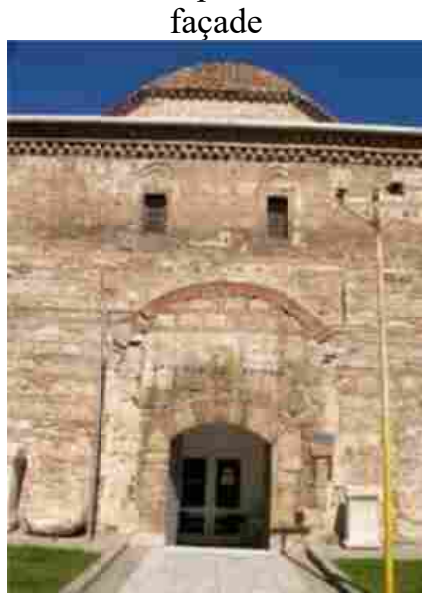

Each of the four doors of the bedesten is a rectangular opening with a segmented arch bordered with almost hewn stone. It is placed, in turn, within an arched recess crowned with a semi-circular arch built of brick (Fig. 9). They were closed with an iron gate. The façades terminate with a triple saw-tooth brick cornice (Fig. 8), a typical byzantine pattern. The roof consists of six blind domes, resting on octagonal drums ( 1 metre high), covered with tiles, which replaced the lead sheets covering the original domes in 1938.

The interior. The building of the interior of the bedesten gains more care than the exterior as the masonry and the traces of ornaments show. The interior in terms of architecture is a rectangular space divided into six square areas by seven double pointed arches resting on two central massive piers (3.17 x 3.28 metres). Both piers are built in kind of cloisonné with large stone blocks in the corners, and its four sides terminate, beneath the springing of the arches, with a decorated frieze of repeated inverted anthemion in stucco (Fig. 10). There are square cavities (25 centimetres across) within the springer of the arches, referring to the positions of the wooden tie beams, which used to connect the arches and exterior walls in all directions. The spaces between the double arches are roofed by thin vaults. The entire structure is roofed with six hemispherical domes ( 7 metres diameter) supported on four rows of stalactites (Figs. 10-11). The transition zone of each dome ends with a decorative band of dog-teeth in brick. The cap of each dome is decorated with a circular panel with floral motives in stucco. Domes and arches are built of brick.

There used to be a wooden bench "mastabah" ( 0.60 metre high and 1.30 metre wide) along the interior walls and around the piers, on top of which the merchandises were shown. ${ }^{44}$

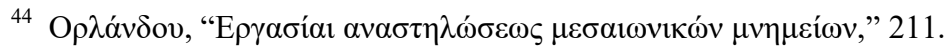


Fig. 10. The Serres Bedesten, one of the two piers on the interior

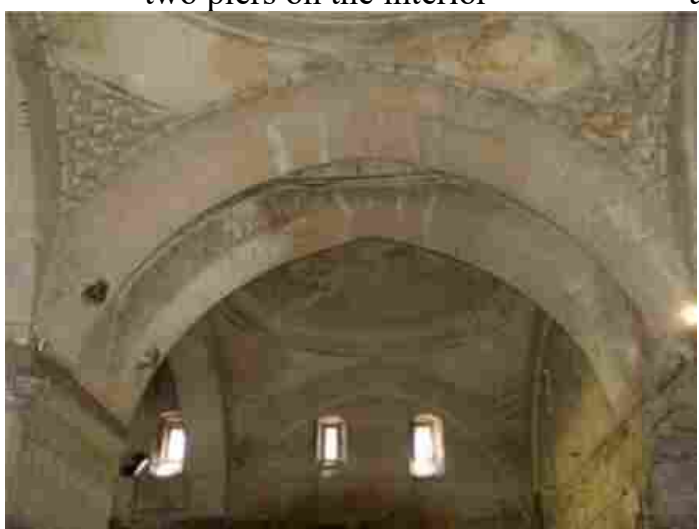

Fig. 11. The Serres Bedesten, the double arches and stalactite transitional zone on the interior

\section{THE THESSALONIKI "SELÂNIK" BEDESTEN}

The bedesten of the city of Thessaloniki ${ }^{45}$ considers one of the most important and well-known bedestens outside Turkey. It is one of the rare examples that retained its original function, the trade of fabrics and precious commodities. The geographer Aş1k Mehmed mentioned this bedesten in $1590 \mathrm{~s}^{46}$ in his book Menazırü'l-Avalim. The rich description of Evliyâ Çelebi underlines the importance and the economic power of the Thessaloniki bedesten, and the diversity and richness of the merchandises present. $\mathrm{He}$ wrote: "the city's [Selanik] bedesten is fortified as the castle, roofed with leadcovered domes, and has iron gates. Its visitors smell musk, amber, and other beautiful fragrances. People are astonished from the jingling of counting the gold and silver when the bedesten's merchants collecting their money, as if they have the treasures of Egypt. It is difficult to describe to what extent the bedesten is overcrowded and very busy.",

The bedesten is located at the intersection of Venizelou and Solomou streets, at the centre of Thessaloniki, at the focal point of the perpendicular of Venizelou and Egnatia streets, the primary longitudinal north-south road that was the usual main street of the city. ${ }^{48}$

The oldest known mention of the Thessaloniki bedesten dates to a $T \bar{a} b \bar{u}$ defter of 877 $\mathrm{AH} / 1472 \mathrm{CE}$; this document states that the bedesten and the surrounding shops were "mülk khāș", i.e. belonging to the Sultan himself. ${ }^{49}$ Based on this information, Cezar attributed this bedesten to the Sultan Mehmed II (the Conqueror 1451-1481), ${ }^{\mathbf{5 0}}$ and dated it to 1455-1459. Thus, the Thessaloniki bedesten was certainly founded before

\footnotetext{
${ }^{45}$ About the history, urban development, monuments of Ottoman Thessaloniki, see: Şemseddin,

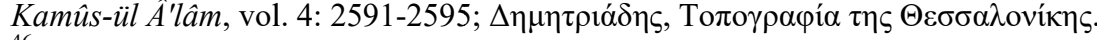

${ }^{46}$ Ak, Aşık Mehmed Menazırü'l-Avalim, Vol.3, 983-992.

${ }^{47}$ Evliyâ \#3, p. 72.; Evliyâ \#5, 8, 158.

${ }^{48}$ A group of important Byzantine and Ottoman buildings located near the bedesten still stands in and around this core, among which the Bey Hamam (Bath of Sultan Murad II; 848 AH/1444 CE), the Hafsa Khâtûn Mosque (also Hamza Bey Mosque and Alkazar; 872 AH/1467-1468 CE), the Ishak Paşa Mosque (or Alaça Imâret; 889 AH/1484 CE), the St. Demetrios Church, and the Yeni Hammam. See: Ameen, Islamic architecture in Greece: Mosques, 53-70.

${ }^{49}$ Gökbilgin, XV - XVI Asirlarda Edirne Ve Paşa Livasi, 152, note 167.

${ }^{50}$ Cezar, Typical Commercial Buildings, 178-183, 215.
} 
the year $877 \mathrm{AH} / 1472 \mathrm{CE},{ }^{51}$ and belonged to the Ottoman Sultan himself. I agree with Cezar's attribution; it corresponds to the increase of bedestens' construction during the reign of the Sultan Mehmed II.

The rental revenues of the bedesten and its shops in Thessaloniki were dedicated to different expenditures. In the second half of the $15^{\text {th }}$ century CE, they, along with many other buildings and possessions in Thessaloniki, were dedicated to cover the running costs of the Sultan Murad II Mosque in Thessaloniki and the buildings of Sultan Bayezid II in Istanbul, ${ }^{52}$ but by the end of the $13^{\text {th }} \mathrm{AH} / 19^{\text {th }}$ century CE, they covered the expenses of the Hamidiye School in Thessaloniki. ${ }^{53}$

Some historical references provide data related to the events and functions of the Thessaloniki bedesten, such as depositing the valuable documents including edicts and decrees of the Sultans. Among these valuable documents deposited in the bedesten, there is a decree dating to $1605 \mathrm{CE}$, listing the names of Muslims and Greeks people authorised to protect the city's walls. ${ }^{54}$ Another reference dating to $1720 \mathrm{CE}$, states the problems of the bedesten, it said: "that the merchants sell the goods at exaggerated prices because of their greed and speculation. As a result, the market lacks security, so there is no guarantee for the orphans' rights or other deposits, because there are no Muslims in the bedesten." 55 This refers to the various aspects of this bedesten, such as keeping deposits, funds, orphans' inheritance, etc., and the supremacy of non-Muslims merchants on trade in the bedesten. This document requests clearly the necessity of the state's intervention in controlling prices and the merchants' profits.

A silver stamp, with inscriptions: Ottoman State "Dawlat 'Othmaniyeh; دولت عثمانيـ" and accurate "sahīh ; صحيح", 56 was found at the northern pier inside the bedesten. Such stamps or weights were used to define the perfect weight of precious metals or the quality and certification of fabrics and other goods.

\section{The Thessaloniki Bedesten Architecture}

The Thessaloniki bedesten is a free-standing building with four façades, with four axial doors. Its rectangular plan measures 19.40 by 29.30 metres, including the walls, surrounded on four sides by external shops that form an external rectangle whose dimensions are 27.20 by 38.20 metres (Fig. 12). It is covered with six parallel hemispherical blind domes resting on octagonal drums carried by seven double arches supported by two central massive square piers (2.90 metres across) and the walls as well. While the external shops are covered with a slightly sloped roof covered with tiles to drain rain. The thickness of the walls is approximately 1 metre to 1.30 metres, since it decreases gradually as going up. The facades are 8 metres high, but the maximum height of the building is 11.50 metres. The masonry is built in cloisonné, but the arches and domes are built only of brick (Fig. 12).

\footnotetext{
${ }^{51}$ About other theories on the founder and foundation date of the bedesten see: $\Delta \eta \mu \eta \tau \rho \dot{\alpha} \delta \eta \zeta$,

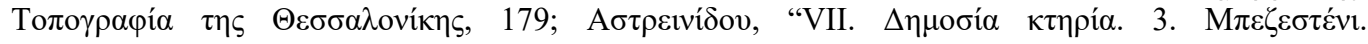

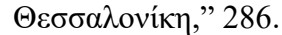

${ }^{52}$ Cezar, Typical Commercial Buildings, 197.

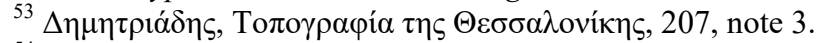

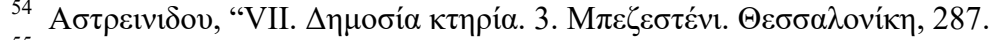

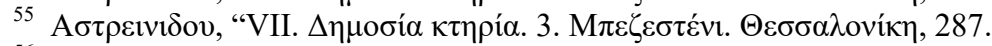

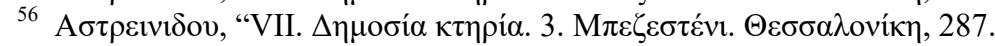


Fig. 12. The Thessaloniki Bedesten, above general view showing the roof \& the NE and SE facades

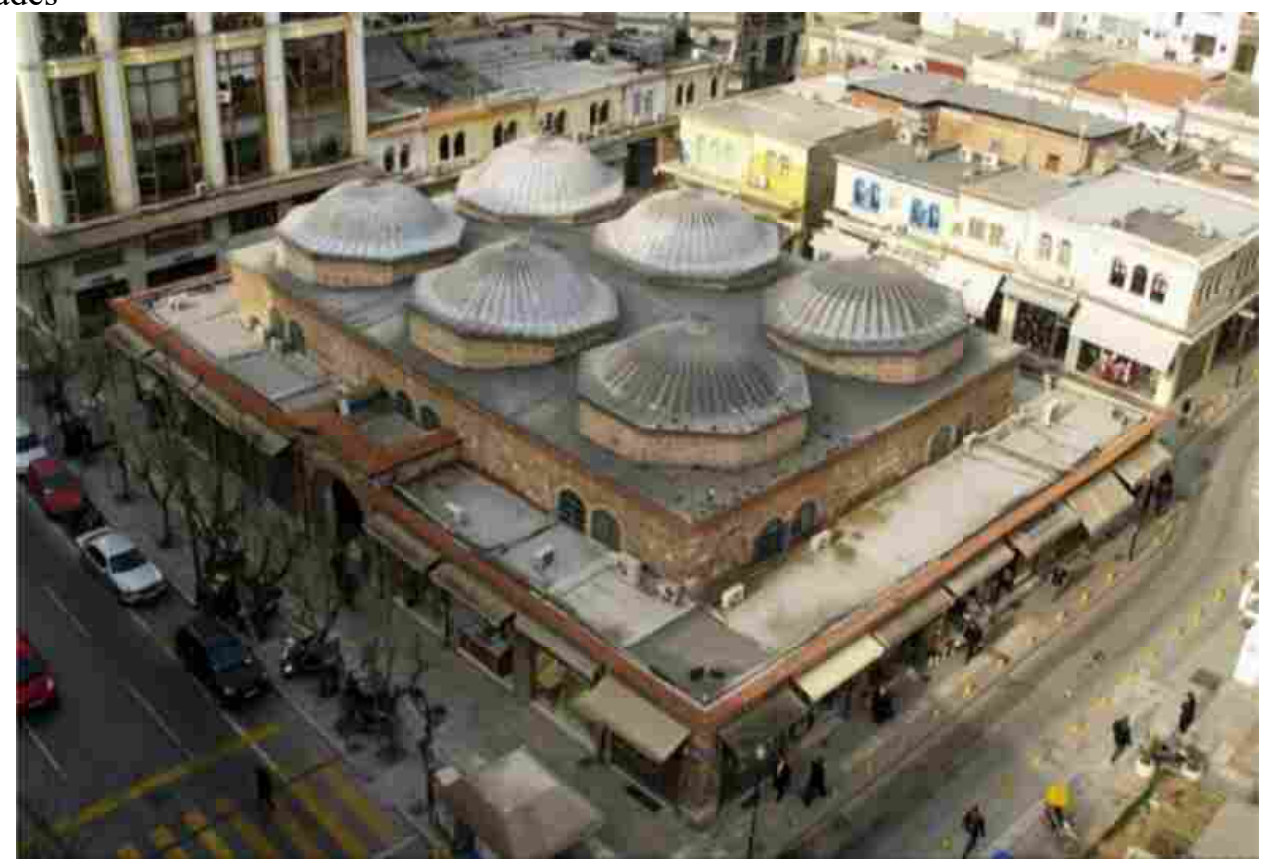

The visible parts of the bedesten's façades show the cloisonné masonry. A tier of twin arched windows runs along the upper section of the facades. These windows were originally small, as those of the Serres bedesten, but they were enlarged during restoration works after the big fire that affected the bedesten in 1917. The different parts of the masonry around these windows show a distinguished brick building than the original cloisonné parts of the facades (Figs. 13, 14).

The exterior shops had another rental value, sold different kinds of merchandise, and were administered by other rules than those of the interior. Before the 1917 fire, the bedesten had 113 shops including the exterior shops. After the restoration works, there were 26 exterior shops (Figs, 12, 17), and 50 overall. ${ }^{57}$ Generally, the waqfiyehs identified these shops as $d \bar{u} k k \bar{a} n$ (pl. dakakinn), and the inner ones as closet "dū $l \bar{a} b$ "58 and store "makhzan," and these shops counted as doors " $b \bar{a} b$;" thus the bedesten described as: "a bedesten with 100 bāb (doors)." "59

The main entrance is in the middle of the longitudinal south-eastern façade which overlooks the Venizelou Street, a main street that crosses the city transversally. The portal is built in a cloisonné topped with a semi-circular arch, its extrados formed by a triple saw-tooth brick frieze, roofed with similar tiles as the exterior shops (Fig. 15). The door opening is rectangular, crowned with a semi-circular arch, within a threetiered arched recess (Fig. 15). The doors close nowadays with new iron doors that have replaced the original gate mentioned by Evliyâ Çelebi.

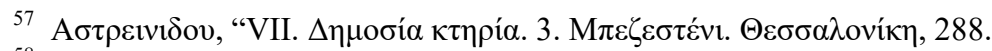

${ }^{58}$ Ayverdi, Avrupa'da Osmanli Mimari Eserleri, 283.

${ }^{59}$ Barkan and Ayverdi, Istanbul Vakıflarl Tahrir Defteri, 43, 346.
} 
Fig. 13. The Thessaloniki Bedesten, the NW façade

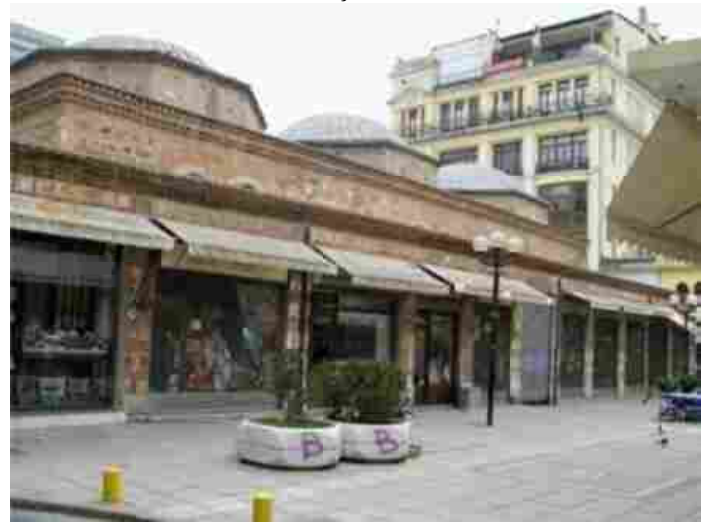

Fig. 15. The Thessaloniki Bedesten, the SE

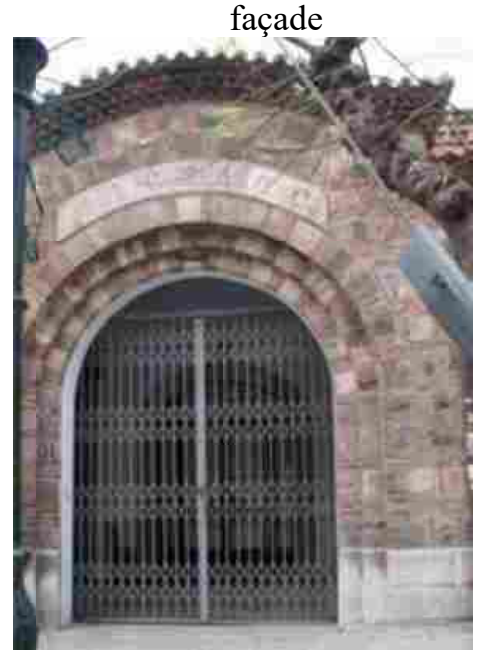

Fig. 14. The Thessaloniki Bedesten, the upper part of the eastern corner on the exterior

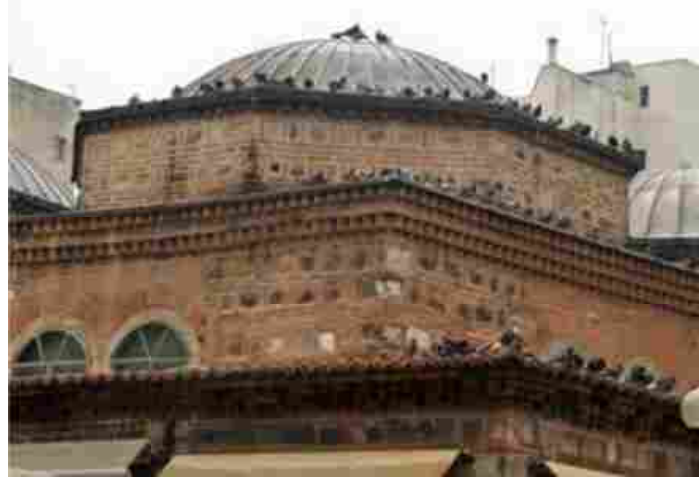

Fig. 16. The Thessaloniki Bedesten, the interior

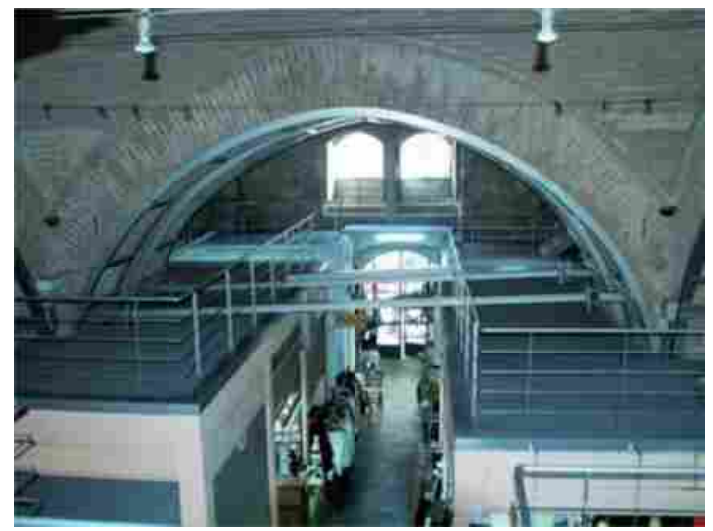

The facades of the exterior shops and the bedesten itself terminate with a triple sawtooth brick frieze (Fig. 16), a typical Byzantine pattern. The roof consists of six blind domes, resting on octagonal drums 1 metre high built in cloisonné and terminating with a triple saw-tooth brick as well. The domes are covered with lead sheets, typical of the Ottoman architecture in the Balkans, and visually distinct.

\section{The interior.}

The interior of the bedesten is almost the same as the Serres bedesten. It is a rectangular space with two central massive square piers (2.90 metres across) dominating the interior and dividing it along with seven double semi-circular arches resting on these piers into six parallel square areas (Fig. 17). The interior walls are built in cloisonné as well. The spaces between these double arches are roofed by thin vaults (Fig. 20). The entire structure is roofed with six hemispherical domes $(6.90$ metres diameter) supported on pendentives (Fig. 19). The traditional wooden tie beams were replaced by modern metal ones during the restoration works carried out in 1982-1985 and 1993-1996 (Figs. 16-20). The cap of each dome is decorated with a circular motif carved in stucco. Domes and arches are entirely built of brick. 
Fig. 17. A plan of the Thessaloniki Bedesten, ground floor level (Ameen, 2016)

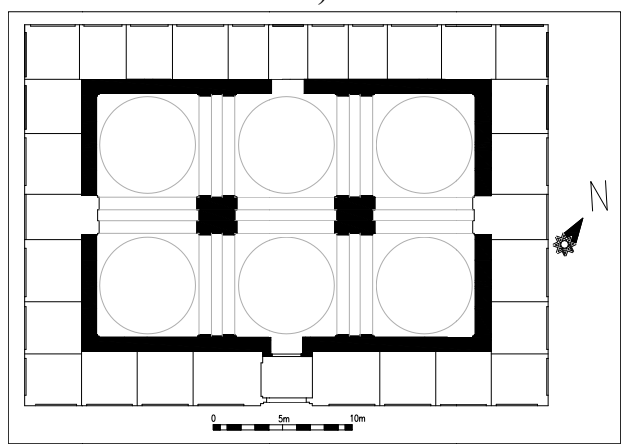

Fig. 18. An interior elevation of the Thessaloniki

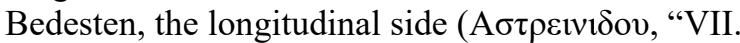

$\Delta \eta \mu о \sigma i ́ \alpha$ ктпрía. 3, 289)

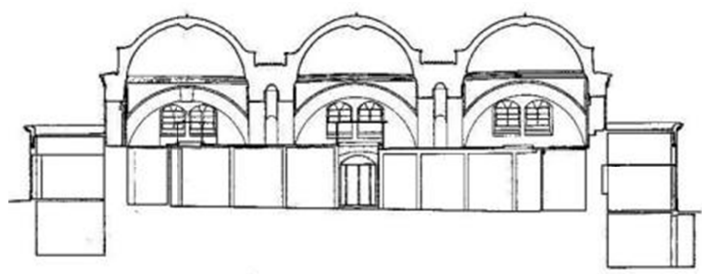

Fig. 19. The Thessaloniki Bedesten, the interior, the double arches and pendentives
Fig. 20. The Thessaloniki Bedesten, the interior, the double arch and the vaulted space between them

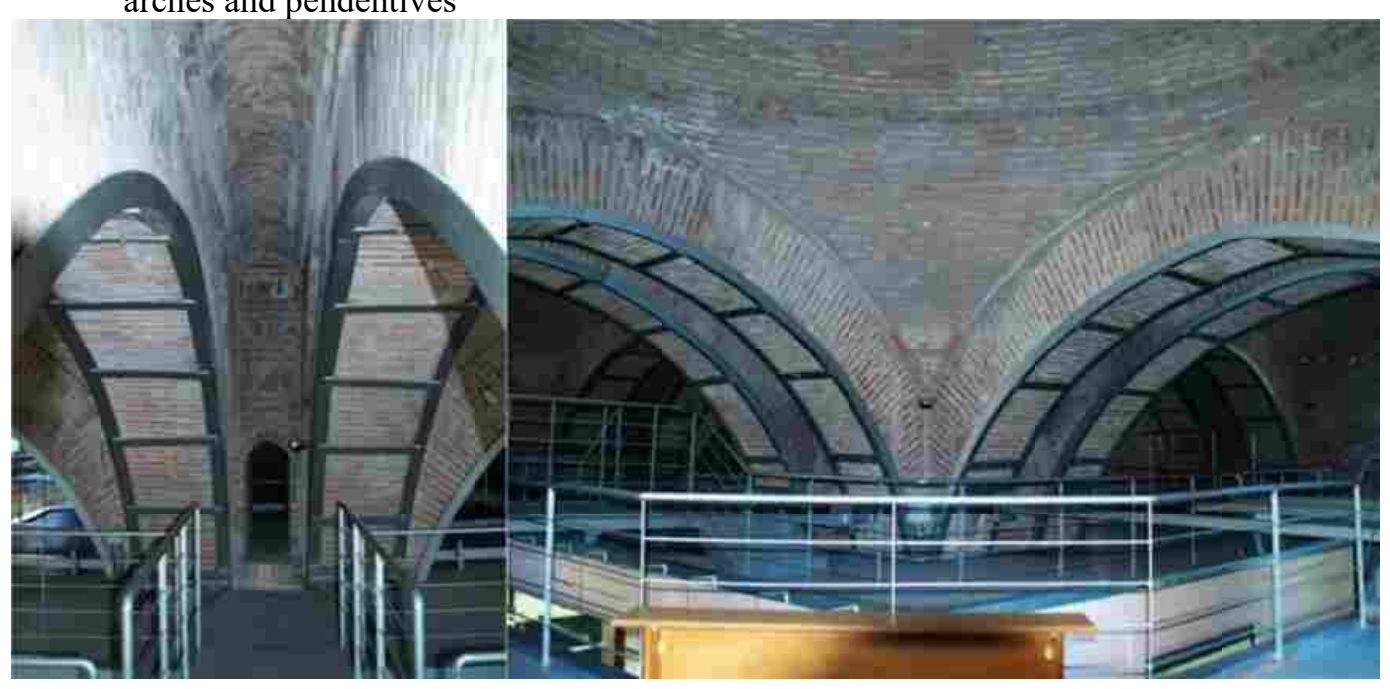

\section{THE LARISSA “YENIŞEHIR, YENIŞEHIR-I FENAR" BEDESTEN}

The Larissa bedesten is the third, and last, surviving one of its kind in Greece. It is partially ruined, as only its exterior walls survive. The massive walls are built with stone and brick, in a rather irregular cloisonné, 1.50 metres thick. Considering the remains, its location and structural characteristics emphasize the architectural essence of Ottoman bedestens, for a building that provides security and protection to merchants and commodities.

The bedesten of Larissa, as mentioned by Evliyâ Çelebi, was built on a flat hill, where the ancient castle could be found. It formed the core of a new city developed from the 1390s onward with thanks to the Ottomans. Larissa was in ruins when the Ottomans came, and they founded a new town as demonstrated by its Ottoman name "Yenişehir" (New City). ${ }^{60}$

${ }^{60}$ Ameen, "Ottoman use of the existing public buildings," 89. 
Fig. 21. The Larissa Bedesten, the exterior

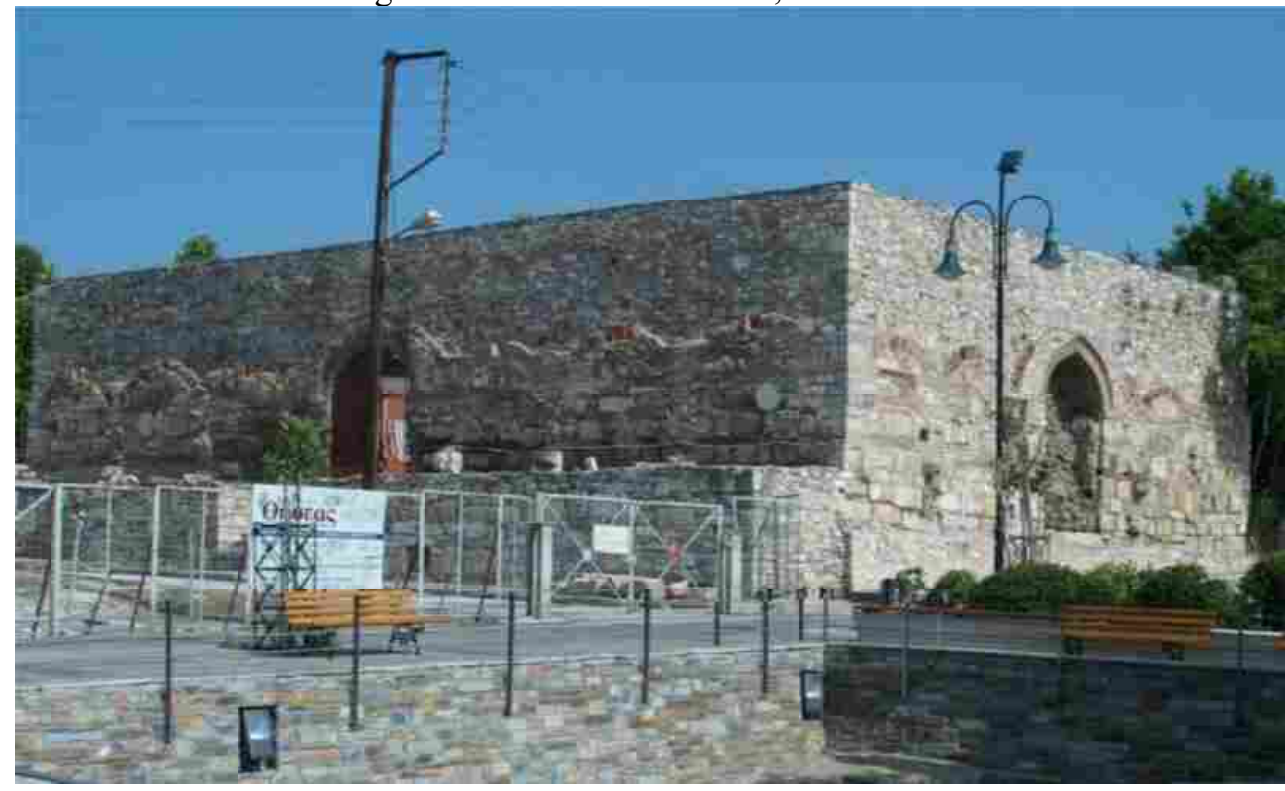

The misidentifying of the Ottoman bedesten as the Byzantine castle resulted from the same location and somewhat similar appearance. Evliyâ Çelebi commented on the fact that the bedesten of Larissa had been built in place of the old fortress, which the Gazi Turhan Bey had destroyed. Its stones were reused in the construction of many Ottoman buildings including the bedesten, ${ }^{61}$ as shown in the latter's walls.

The bedesten was built on low plateau formed the core of the new developed city. Evliyâ described the bedesten: "In the centre of the city is the massive stone bedesten, as the city's fortified castle, with strong walls, it has four iron gates, and inside which the merchants are selling their precious commodities." 62

The waqfiyeh (Fig. 22) of Hac1 Ömer Bey ${ }^{63}$ the son of Hac1 Turhan, dated to Muharram $889 \mathrm{AH} /$ February $1484 \mathrm{CE}$, is the earliest reference mentioning the Larissa bedesten. This waqfiyeh was devoted for his many buildings in the cities of Trikala and Larissa, and some nearby villages. This corrects the misdating of the bedesten by Kiel and Deriziotis, in their valuable study about the reconstruction of this bedesten, who stated that the previous waqfiyeh did not mention the bedesten, and "the first notice of its existence was found by Yusuf Halaçoğlu ${ }^{64}$ in the Ottoman census register of Thessaly from $912 \mathrm{H}$. (1506/1507). ${ }^{65}$ This study concluded that the foundation date of the Larissa bedesten was between the years 889-911AH/1484-1506 CE.

Indeed, the earlier waqfiyeh of Hac1 Ömer Bey the son of Hac1 Turhan mentioned clearly the bedesten of Larissa "Yenişehir", and it is understood from the text that it

\footnotetext{
${ }^{61}$ Evliyâ \#3, p. 87.; Evliyâ \#5, 8, 190.

${ }^{62}$ Evliyâ \#3, p. 88.; Evliyâ \#5, 8, 192.

${ }^{63}$ VGMA, Defter nr. 743, s. 133-137, sira 29; Eren, Oğuz and Mete, Balkanlar'da Osmanlı vakıflarl, vol. 4: 12-14, vol. 5: 558-560.

${ }^{64}$ Halaçoğlu, "Teselya Yenişehirli ve Türk Eserleri Hakkında Bir Araştırma," 92.

${ }^{65}$ T. D. 36, The Başbakanlık Arşivi in Istanbul; Kiel - Deriziotis, "The old bedesten of Larissa, 143, the next references copied the same content of Kiel and Deriziotis such as: $\Sigma \delta \rho o ́ \lambda \iota \alpha$, “Тo М $\pi \varepsilon \zeta \varepsilon \sigma \tau \varepsilon ́ v ı$

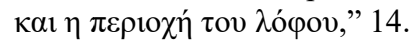


has been in existence for some time. Hence, the waqfiyeh did not describe it as "new", as it did regarding the "new" khan just described after, or in sequence the other "new" shops. Thus, the foundation date of the Larissa bedesten must be before the year 889 $\mathrm{AH} / 1484 \mathrm{CE}$. It is likely that it was built soon after the Thessaloniki bedesten.

This dating of the Larissa bedesten and the other two surviving bedestens in Greece match the reign of Sultan Mehmed II (1451-1481), which was a flourishing era for bedesten architecture. This also confirms that the founder of the Larissa bedesten was the Hacı Ömer Bey son of Hac1 Turhan, as Kiel and Deriziotis stated. A translation of the text concerning the Larissa bedesten quoted from the Arabic waqfiyeh of Hac1 Ömer Bey states: "and the entirely new khan and new shops located in the core of the aforementioned city, which is well-known and no needs to define, and also endowed all the bezzazistan [bedesten] and the new khan / and the store which called the qabban, and the store called bashkhane; in which the heads and knuckles sold, and all the shops around it that located in in the township of Yenişehir [Larissa], the protected and the defined as a whole by the main road which runs from the old hammam [bath] from the east, and the main road and the empty land which is waqf for the Burak Bey from south, and the shops attributed to the late Turhan Bey and those attributed to Burak Bey from the west, and the Old Mosque from north."66

The Larissa bedesten consists of a rectangular plan measuring 20 by 30 metres, including the walls, which enclose an inner space 17 by 27 metres. It is almost identical to both the bedestens of Serres and Thessaloniki. Spoila from ruined antique buildings including the ancient fortress, columns' parts, large pieces of marble and stone, were reused to build the walls of the bedesten. ${ }^{67}$ It is a free-standing building with three axial doors on the three southern, eastern and western facades, while the northern facade comprises a large recess of 3.55 metres across by 4.50 metres in depth, which does not open into the bedesten. It seems that this recess was used as the treasury house of Larissa ${ }^{68}$ in accordance to the characteristic function of the Ottoman bedestens for depositing money, jewellery, precious commodities, and valuable documents. However, this recess may have been modified to this uncommon form, as a closed area, replacing the fourth traditional gate of the bedesten on this side, after 1668 when Evliyâ Çelebi saw the bedesten, as he stated that the bedesten had four iron gates. ${ }^{69}$

Kiel and Deriziotis suggested a perfect reconstruction ${ }^{70}$ (Fig. 23) to this bedesten considering the surviving walls and the visible architectural traces of the springs of the vaults, which covered the exterior shops, and the interior double arches. It also included data revealed by the Archaeological Service of Thessaly excavations, such as the base of one of two central square massive piers (2.70 metres across).

The Swedish orientalist and traveller Jakob Björnståhl visited Thessaly in 1779, and mentioned the bedesten of Larissa and its roof of lead-covered domes. ${ }^{71}$ It seems that the bedesten suffered from the 1781 earthquake. Thus, it was in a very bad condition

${ }^{66}$ - VGMA, Defter nr. 743, s. 133-137, sıra 29 ; Vakfiyeler Yunanistan, vol. 4: 9, vol. 5: 558-560.

${ }^{67} \mathrm{Kiel}$ - Deriziotis, "The old bedesten of Larissa, 143.

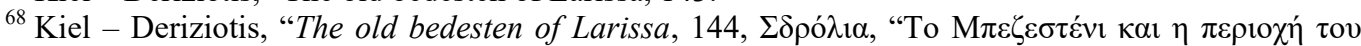

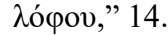

${ }^{69}$ Evliyâ \#3, 88.; Evliyâ \#5, 8, 192.

${ }^{70}$ Kiel - Deriziotis, "The old bedesten of Larissa, 143-145.

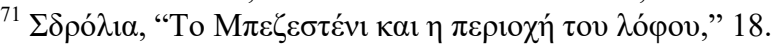

- 133 - The Ottoman bedestens in Greece 
during the last decades of the $18^{\text {th }}$ and the $19^{\text {th }}$ centuries. It was used by the Greek army in $1881 \mathrm{CE}$, when the city returned to the Greeks. The interior remained ruined and full of rubble and earth until 1970, when the Greek Archaeological Service of Thessaly removed these heaps and cleared the site. ${ }^{72}$ The building is still in urgent need of restoration and reconstruction, as well as a suitable re-employment.

Fig. 22. The Arabic waqfiyeh of Hacı Ömer Bey (889 AH/1484 CE): (A) the $2^{\text {nd }}$ page, (B) a detail that mentions the Larissa "Yenişehir" Bedesten

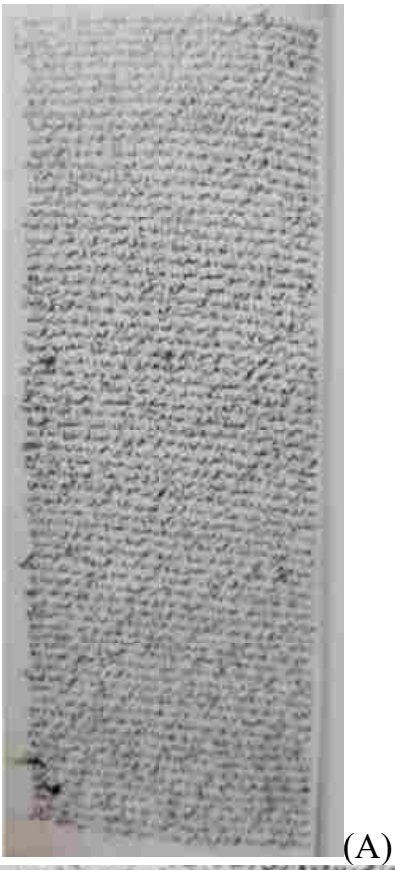

A)

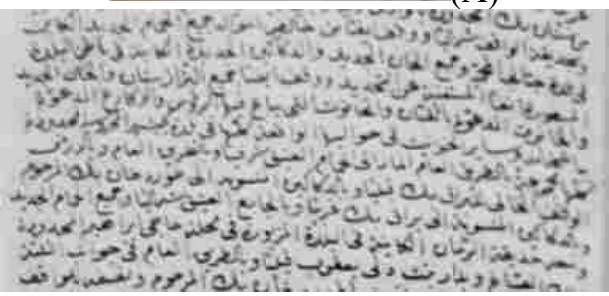

(B)
Fig. 23. A reconstruction plan of the Larissa Bedesten (Source: Kiel -Deriziotis, The old bedesten of Larissa: (A) A plan, (B) a perspective; reconstruction Machiel Kiel, drawing Gerd Schneider)

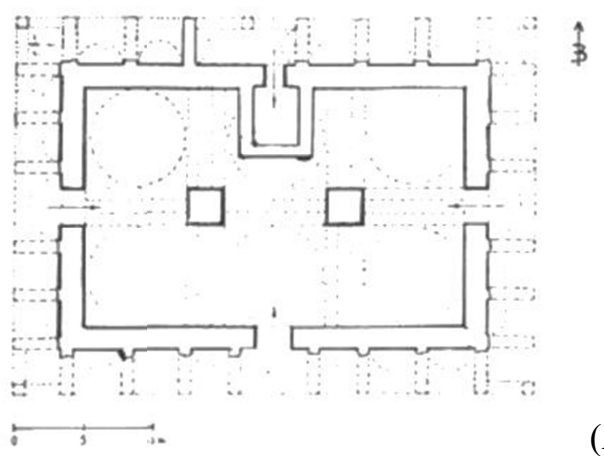

(A)

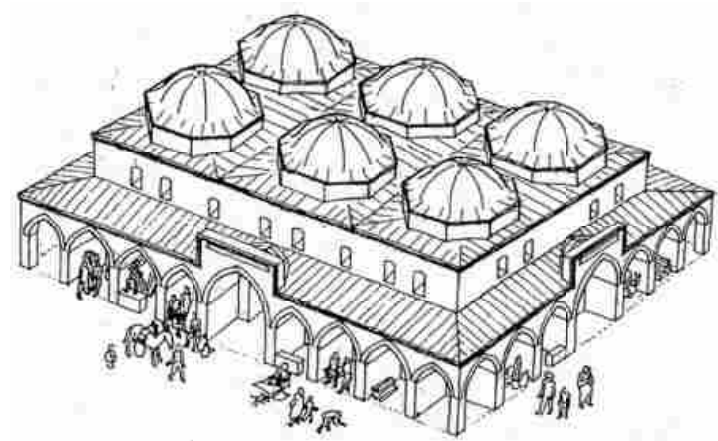

(B)

\section{DISCUSSION}

\section{The bedesten: the origins, function and architectural form}

It seems that the instability and turmoil which characterised the late Seljuk ${ }^{73}$ times (1077-1308) in Anatolia -and the fall of Konya by the hands of the Mongol Ilkhanate, and the independence of the Turkish Beys and the formation of the

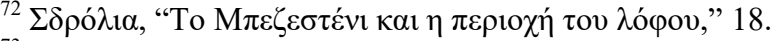

${ }^{73}$ Seljuk cloths' bazars, with different names bezzaziye khan, iplikçi khan, and dokumacı khan, dedicated to the manufacture and trade of fabrics, were the first step toward forming the bedesten. See: Cezar, Typical Commercial Buildings, 160.
} 
Anatolian Beyliks ( $2^{\text {nd }}$ half of the $13^{\text {th }}$ c.)- were beyond the need of such a massive well-protected ${ }^{74}$ building for trading fabrics, embroidery, and precious goods, as the bedesten.

The architectural layout of these khans is almost the same as the parallel caravanserai; a massive stone building with a single gate which has a central courtyard surrounded by riwaq, fronted the merchants' rooms and stores. Some waqfiyehs of the Anatolian Beyliks, prior to the Ottoman state, refer to the presence of the bezzaziye khan in late $7^{\text {th }} \mathrm{AH} / 13^{\text {th }}$ century $\mathrm{CE}$ and early $8^{\text {th }} \mathrm{AH} / 14^{\text {th }}$ century $\mathrm{CE}$. The waqfiyeh of the Grand Mosque "Ulu cami" 75 (696 AH/1296-1297 CE) in the name of Emir Eşrefoğlu Süleyman Bey in the city of Beyşehir in Konya, mentions among the waqfs "the bezzaziye khan and the surrounding shops", in reference to the existence of a building very similar to the Ottoman bedesten, known as the Eşrefoğlu Süleyman Bey bedesten (Figs. 24, 25). ${ }^{76}$ Emir Khan (bezzaziye khan, also known as the old bedesten) ${ }^{77}$ founded by the Orhan Gazi in Bursa, is an important transitional building towards the Ottoman bedesten. The Bursa bedesten ${ }^{78}$ (802 AH/1400 CE) of Yildırım Bayezid (r. 791-805 AH/1389-1402 CE) is the oldest surviving Ottoman bedesten, and formed its architectural prototype (Fig. 26 [7], 27). The Bursa bedesten with its characteristic architecture was the prototype of the subsequent Ottoman bedestens,

\footnotetext{
${ }^{74}$ Kuban, Osmanlı Mimarisi, p. 158.

${ }^{75}$ About the content of this waqfiyeh and other stone waqfiyehs, see: Çetinaslan, "Taş Vakfiyeler ve Beyşehir Eşrefoğlu Camii'nin Taş Vakfiyesi,” 219-251.

${ }^{76}$ This building was long considered the oldest surviving bedesten, and the architectural prototype of the Ottoman bedesten (see: Yavuz, Eșrefoğullari Tarihi Beyșehir, 43; Cezar, Typical Commercial Buildings, 163; Eyice, "Bedesten," 305). This was until its foundation inscription was discovered during the restoration works on the building in 1930s, stating that was reconstructed by Çavuşbaş1, and the last chronogram according to hisab aldjumual gives the date $955 \mathrm{AH} / 1548 \mathrm{CE}$. Çaycı believes that the now standing building has been reconstructed the same as the old one; if this is correct it would be considered the oldest surviving bedesten, but the characteristics of its architecture does not support this assumptions. See: Çayci, Eşrefoğlu Beyliği Dönemi Mimari Eserleri, 62-65. The current building replaced the older bezzaziye khan which was mentioned in the stone waqfiyeh above the main door of Eşrefoğlu Süleyman Bey Mosque. The new architectural form of this building emphasises this point of view. Thus, the oldest known bedesten in term of architecture is the Bursa bedesten $(802 \mathrm{AH} / 1400 \mathrm{CE})$ founded by Yıldırım Bayezid (r. 1389-1402).

${ }^{77}$ In terms of architecture, it is a typical Seljuk or early Ottoman khan as the neighbouring Fidan and Koza khans in the core of Bursa (Kuban, Osmanlı Mimarisi, 156-157). It is a massive two-storey stone building that has an open courtyard surrounded by a riwaq on four sides. This riwaq fronted the rooms and stores. While the rooms of the ground floor have no windows, the upper floor ones were intended for residence as shown by their windows and fireplaces (Ayverdi and Aydin, Ilk 250 senenin Osmanli mimarisi, 105). It seems that only the first floor functioned as the bezzaziye khan, a common pattern in early Ottoman bedestens. See: Cezar, Typical Commercial Buildings, 170.

${ }^{78}$ It is a massive structure with rectangular plan; its dimensions including the walls $35.5 \times 71.7$ metres, comprises 32 rooms inside, surrounded by 68 shops on the exterior. See: Kuban, Osmanl Mimarisi, 158. The Bursa bedesten is an elongated rectangular building covered by fourteen identical domes over two rows. It seems that the multiple covering domes were a direct influence from the adjacent Ulu cami, of the same founder Bayezid I the Yıldırım. This very elongated layout characterised also the early Ottoman khans as the Evrenos Bey khan in the Greek Thrace (1370-1390) which has a rectangular plan 10.20 x 25.80 metres (See: Kiel, "The Oldest Monuments of Ottoman-Turkish Architecture," 133-138), and Issiz Khan in Uluâbad (797 AH/1394-1395 CE), with dimensions 22 x 42 metres. See: Ayverdi, İstanbul Mimari Çă̆ının Menşei, 526-530, Figs. 899-907. This characteristic elongated layout may effect on the architecture of the Ottoman bedesten.
}

\footnotetext{
- 135 - The Ottoman bedestens in Greece
} 
such as the Çelebi Sultan Mehmed bedesten in Edirne, Fatih Sultan Mehmed bedesten in Istanbul, and Mahmud Paşa bedesten in Ankara.

\section{The functions of the bedesten}

The original function of the bedesten, as the name indicates, was the trade of fabrics and clothes. Historical sources, including Evliyâ Çelebi, state that the bedesten was a building where the most valuable fabrics, commodities along with silver, gold and jewellery were available. As such, it was the forum of wealthy merchants.

Fig. 24. A plan of the Eşrefoğlu Süleyman Bey Fig. 25. The Eşrefoğlu Süleyman Bey Bedesten Bedesten (Source: Cezar, Typical Commercial (https://www.flickr.com/photos/sinandogan/149202939 Buildings, Fig. 108)

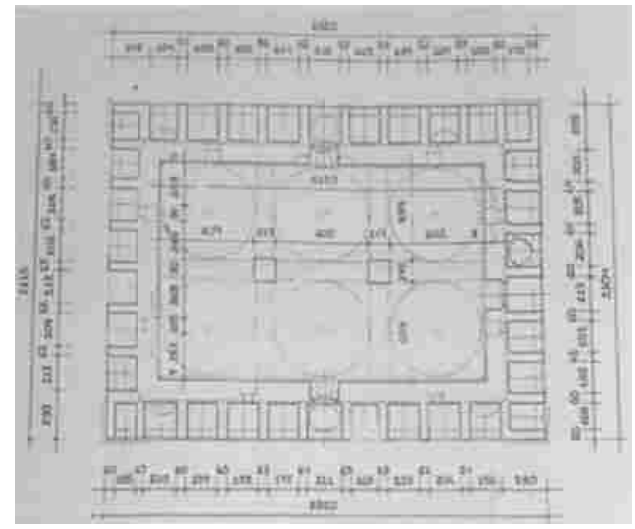

55) [Access Date: Nov. 20, 2019]

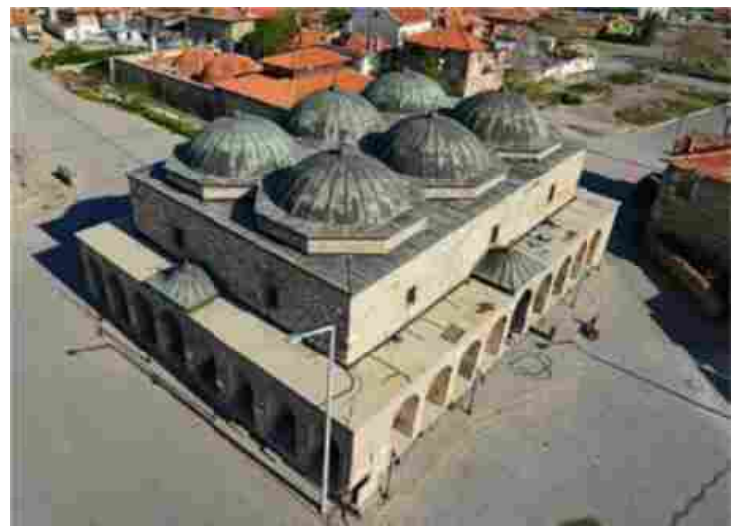

Figs. 26. The commercial centre of the city of Bursa (Kuban, Osmanlı Mimarisi, 157)

1. Ulu cami

2. Orhan Bey İmaret

3. Fidan Khan

4. Koza Khan

5. Orhan Hammam

6. Geyve Khan

7. The Bedesten

8. Emir Khan

9. Sipahiler bazar

10. Şengül Hamma

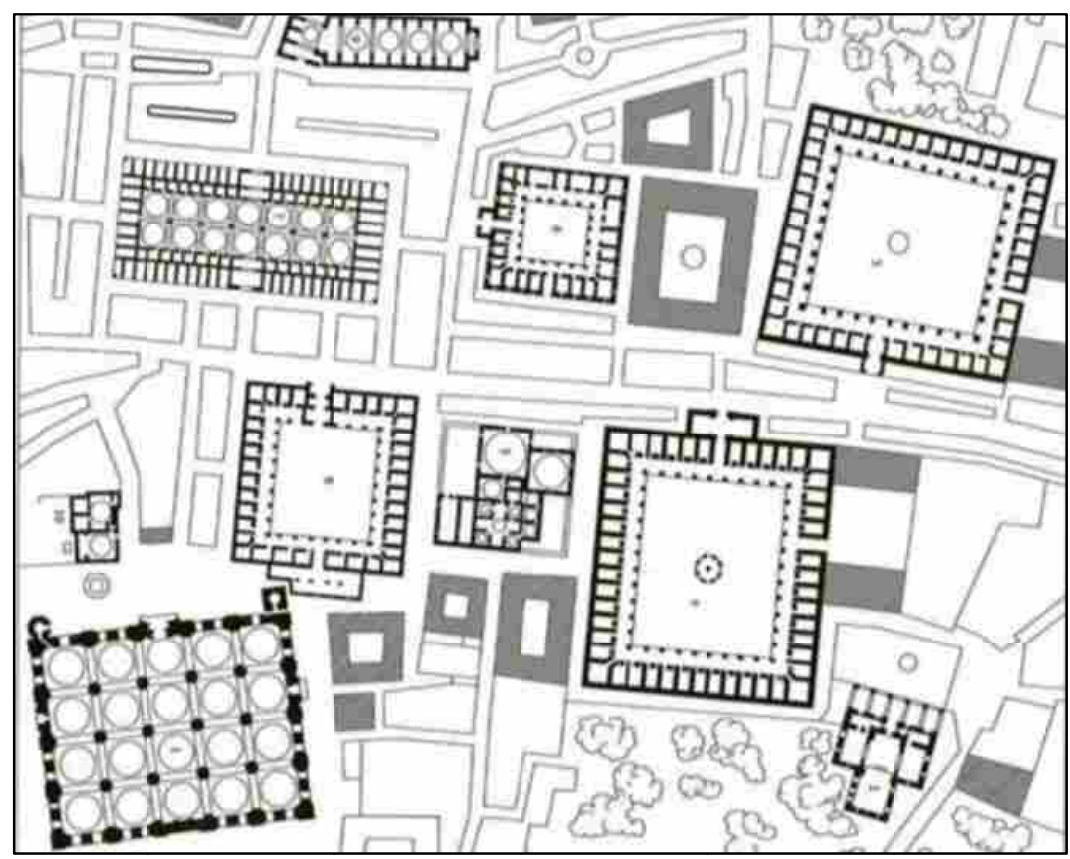


Figs. 27. The Y1ldırım Bayezid Bedesten of Bursa

(Ayverdi \& Aydin, Ilk 250 senenin Osmanli, p., 133)

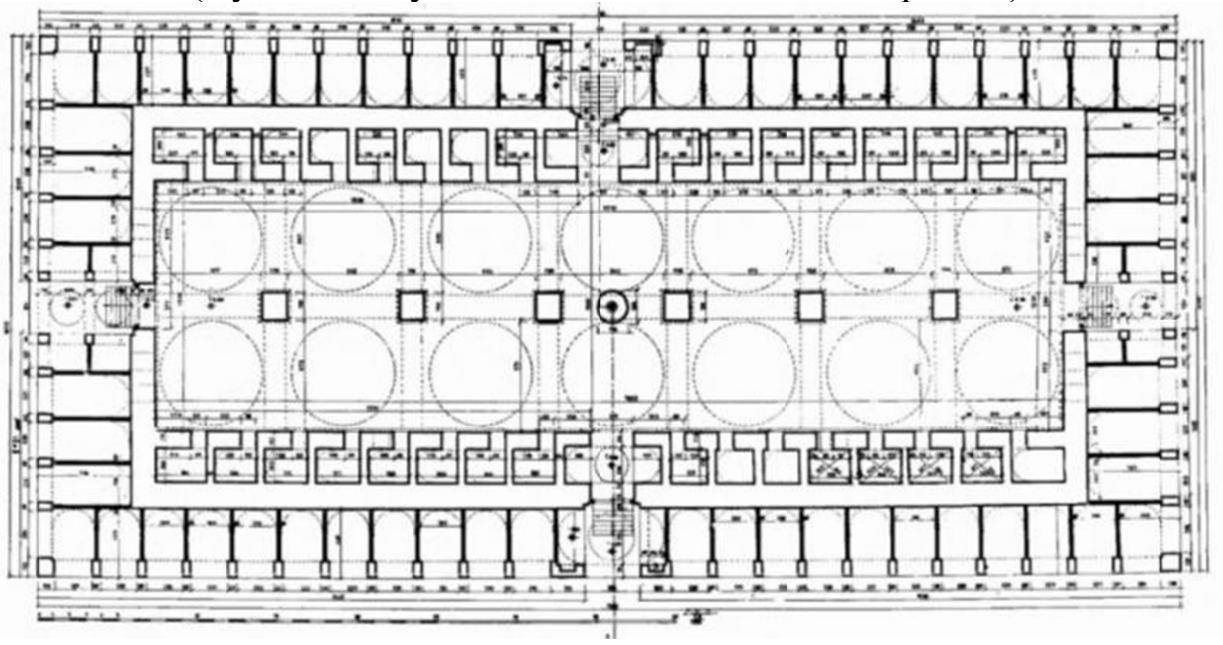

The Bursa bedesten shows the new functional system side by side with its original one, ${ }^{79}$ trade of fabrics and textiles. Indeed, the functions differed from a bedesten to another considering its location, and its commercial capacity. This affected the architecture, size and additional functions of the bedesten. The bedesten location and size were also matched with the merchants' perspective, kinds of goods, number of employees along with their jobs and duties. Hence, the bedestens within the main and high commerce cities held more functions and hired more employees than others.

The bedesten took the power and almost the responsibilities of the trade guilds concerned with its commercial activities. ${ }^{80}$ Though the bedesten originated as a waqf (vaklf) to cover the payments of the religious and social buildings of the founder, it gradually became a semi-official commercial and economic institution, representing the state authority, ${ }^{81}$ and its commercial policies.

Usually, most high quality fabrics and clothes were available from everywhere ${ }^{82}$ in the bedesten. If the city of the bedesten was famous for the production of a specific type of fabrics, such as silk in Bursa, it awarded priority to this trade and its merchants. ${ }^{83}$ Jewellers and goldsmiths had their own shops in the bedesten. ${ }^{84}$ In addition, it was also within the bedesten's grounds that the state enforced the responsibility of price and quality control, through the monitoring of the exchange and the numismatics values. ${ }^{85}$

\footnotetext{
${ }^{79}$ Cezar, Typical Commercial Buildings, 230.

${ }^{80}$ Dalsar, Bursa'da Ípekçilik, pp. 100, 148-149.

${ }^{81}$ Cezar, Typical Commercial Buildings, 239.

${ }^{82}$ Inalcik, "İstanbul'un İncisi: Bedesten," 131.

${ }^{83}$ Cezar, Typical Commercial Buildings, 230-231; Inalcik and Quataert, An Economic and Social History, vol. 1, pp. 218-255.

${ }^{84}$ Cezar, Typical Commercial Buildings, 231.

${ }^{85}$ Cezar, Typical Commercial Buildings, 231, 238.
} 
A new function allowed the renting of a private locker or treasury ( $d \bar{u} l \bar{a} b$, closet) in the bedesten to deposit precious possessions including jewellery, money, official documents, waqfs revenues, custody, trusts, commodities and any other private items. ${ }^{86}$ Depositing the surplus of waqf revenues in a treasury within the bedesten ${ }^{87}$ was new, in Islamic architecture, to the bedesten and to the waqf system. The waqfiyeh of Daoud Pasha (Davud Paşa) ${ }^{88}$ on his buildings in Istanbul mentioned that the surplus income should be deposited as a trust in the bedesten, ${ }^{89}$ to be used when necessary. It is an Ottoman enhancement to the waqf administration system.

These deposited belongings could be collected personally by the owner or by an authorised party. In the death of the depositor, the belongings were first recorded in the court records, then handed over to his legal heirs. ${ }^{90}$

Hence, the bedesten was a semi-governmental economic and commercial institution, playing a major role in connecting the state and the merchants. This is where the main commercial activities were performed within Ottoman cities.

\section{The merchants and employees of the bedesten}

The bedesten's merchants rented the shops of the bedesten for their commerce. In Ottoman bedestens there was no priority for Muslim merchants. ${ }^{91}$ The bedesten's owner made sure that the merchants had good reputation, and were honest and trustworthy. They participated as experts in the courts regarding the commercial issues that required their opinions or evaluation. ${ }^{92}$ As a result of the traders' good reputation, some waqfiyehs recommended them as trustees for the waqfs in the case that all the endower's family members have been deceased, as explained in the medrese's waqfiyeh of the deceased Mawlana Ahmed (925 AH/1519 CE). ${ }^{93}$

The main reference providing data regarding the employees of the bedesten and their duties is the work of Evliyâ Çelebi. Their main professions were the katkhuda (kethüda), dallāl (dellâl), guards (hāris; the word used by Evliyâ borrowed from Persian: pâsbân "بپاسبان" meaning sentry, night watchman and guard) and porters (hammäl; hammâl). The katkhuda was appointed by the founder -then the state for the Capital's bedestens- from the merchants of the bedesten. He was responsible for the overall management of the bedesten, and the spokesman of its merchants. ${ }^{94}$ Sometimes, he had the difficult task to balance between the state's trading policies and the interests of the merchants. The katkhuda of the big bedestens especially in the Istanbul, had other advantages and tasks, including supervising with the defterdar the

\footnotetext{
${ }^{86}$ Inalcik, "The Hub of the city: the Bedestan," 2; Ergin, "Bedestan," 440-442; Cezar, Typical Commercial Buildings, 235.

${ }^{87}$ Cezar, Typical Commercial Buildings, 235.

${ }^{88}$ Barkan and Ayverdi, İstanbul Vakıflart Tahrir Defteri, 345-347.

${ }^{89}$ Barkan and Ayverdi, Istanbul Vakıflart Tahrir Defteri, 347.

${ }^{90}$ Further data about these lockers see: Akar, "Osmanlı Kentinde Ticari Mekânlar," 269-270.

${ }^{91}$ Inalcik, “İstanbul'un İncisi: Bedesten,” 126-127; Cezar, Typical Commercial Buildings, 231, 234.

${ }^{92}$ Göyünç and Özbilgen, Eski Malatya'da Silâhdar, 84-88; Cezar, Typical Commercial Buildings, 234.

93 Barkan and Ayverdi, İstanbul Vakıflarl Tahrir Defteri, no.1137, 199-200; Cezar, Typical Commercial Buildings, 234.

${ }^{94}$ Cezar, Typical Commercial Buildings, 231.
} 
precious metals used in the mint ${ }^{95}$ (Dār al-darb, darbhâne; ضرب خانه), charging the exchange, and recording its values in specific books. ${ }^{96}$ His multiple responsibilities and missions ${ }^{97}$ reflected his high status among the elite of contemporary Ottoman society.

Evliyâ Çelebi informed us that the bedesten had two categories of dallāl: inside the bedesten and outside. He continued by describing the employment requirements and the duties of each. ${ }^{98}$ The dallāl inside the bedesten had the responsibility to keep the security and order inside the bedesten, and to act as a commissioner or broker between wholesalers in the bedesten and the retailers outside. The dallāls had to be honest and trustworthy to work in the bedesten; thus the Katkhuda would often ask for a reference to employ them. In Istanbul the dallāls needed to obtain a royal decree ${ }^{99}$ from the defterdar to work in the bedesten. Among the dallāls was appointed a dallālbashi, head of the dallāls. ${ }^{100}$

Evliyâ stated that the guards of the bedesten must be Muslim, honest, and trustworthy. ${ }^{101}$ They were responsible to light the lamps inside the bedesten, and guarding its streets at night. ${ }^{102}$ The porters' main job was to help the merchants outside the bedesten. ${ }^{103}$

In addition, there were other positions, especially in the larger bedestens, such as prayer singers, ${ }^{104}$ who occasionally worked on religious holidays, and the cloth stamping officer (damagac1/دمغجي، أمين الدمغة) who was responsible for the quality of fabrics and clothes control. ${ }^{105}$

\section{The bedesten and the urban landscape of the "Ottoman" city}

The bedesten as a focal commercial building became a characteristic pattern of the Ottoman cities, especially the major trade centres. It can be said that Evliyâ Çelebi categorised the Ottoman cities into two categories, cities with bedesten, and cities without. ${ }^{106}$ In most Ottoman main cities along the trade routes, there was only one bedesten; some cities contained two bedestens and only in Istanbul were there three. $^{107}$

The bedesten shaped the urban landscape of the centre of the Ottoman city, by completing the three existing traditional buildings: the mosque, medrese, and hammam. This change added a dynamic component to the plan of the Ottoman city. It

\footnotetext{
95 Ahmed Rafik mentions important information about the golden coins and their weights of great importance in the economic analysis of that period, see: Refik, Hicri On İkinci Asirda, 217-218; Cezar, Typical Commercial Buildings, 238, 249 n. 177.

${ }^{96}$ Sohailoglu published examples of these registers dating to the 11th AH/17 CE century, and analysed the included numismatics values in an economic context, see: Sahillioğlu, "XVII. Asrın İlk Yarısında," 227-233; Cezar, Typical Commercial Buildings, 238.

${ }^{97}$ Aktepe, Şem 'dânîzâde Fındıklılı Süleyman, 128-129; Cezar, Typical Commercial Buildings, 239.

${ }^{98}$ Evliyâ \#8, p. 618; Halaçoğlu, "Dellâl,” 145-146; Dalsar, Bursa'da Ípekçilik, 1960, 100.

${ }^{99}$ Cezar, Typical Commercial Buildings, 232.

${ }^{100}$ Dalsar, Bursa'da İpekçilik, 1960, 224.

${ }^{101}$ Evliyâ \#8, 618.

102 Cezar, Typical Commercial Buildings, 232.

${ }^{103}$ Evliyâ \#8, 618.

${ }^{104}$ Cezar, Typical Commercial Buildings, 233.

${ }^{105}$ Cezar, Typical Commercial Buildings, 232.

${ }^{106}$ Kreiser, "Bedesten-Bauten im Osmanischen Reich,"367-400, 368.

${ }^{107}$ Eyice, "Bedesten," 302 ; Kreiser, "Bedesten-Bauten im Osmanischen Reich", 367-400, 367-368; Cezar, Typical Commercial Building s,166.
}

- 139 - The Ottoman bedestens in Greece 
had a distinct visual impact to the core of the city distinguishing easily the typical landscape of the cities which have a bedesten from those without. The bedesten's site in the core of the city, the distinguished architectural form and the circular movements characterised the centre of Ottoman cities with a bedesten.

\section{CONCLUSIONS}

This paper focused on clarifying the number of Ottoman commercial buildings known in Greece over time, considering their sites in relation to the main stops on trade routes. Their increased implantations along the Via Egnatia, the main trade route across Northern Greece connecting Istanbul and Edirne with Albania and Italy, are underlined. This is especially notable in the cities of Alexandroupoli, Xanthi, Serres, Drama, Kavala, Thessaloniki, Veria, Larissa, Trikala and Ioannina. The study surveyed the Ottoman bedestens in Greece by the end of the Ottoman rule and now; there were seven bedestens, five of which were within cities located along the Via Egnatia; in addition, the one in Larissa is rather close; the last bedesten was on the island of Rhodes. Only three bedestens still exist, located in Serres, Thessaloniki and Larissa - the latter is semi ruined.

The bedesten is an Ottoman creation in term of urban planning, architecture and function. It characterised the centre of significant Ottoman cities, distinguishing them from the other Ottoman cities without bedesten, and other Islamic cities. It added a fourth characteristic building to the trinity architectural composition of the centre of the Ottoman city, the mosque, the medrese, and the hammam. Hence, the cities which have bedesten show a different visual layout from those without. The almost identical and distinct architectural form of the bedesten emphasizes this visual pattern.

The bedesten's architecture is strongly connected to its functions. Their architectural form is noticeably similar in the frequent bedestens' description mentioned by Evliyâ Çelebi throughout the territories of the Ottoman Empire. These iconic buildings are composed of a massive well-protected stone building, covered with lead-sheets domes, with four axial iron gates. The site and characteristics of the bedesten architecture fulfil its traditional and innovative functions. It provides a closed protected hall for the trade of the best kinds of fabrics, jewellery, precious commodities. It also offers private safes for storing and depositing money, important documents and various possessions.

This paper concludes with the following results:

- The Ottoman bedesten was a semi-official commercial and economic institution; controlled by the State. The structure reflected its financial, economic and commercial policies.

- The merchants of the bedesten were both Muslims and non-Muslims.

- Rental revenues of the bedestens, as other commercial structures, were dedicated to cover the costs of the religious, educational and social buildings of the same patron.

- The bedesten architecture witnessed a remarkable development and spreading during the reign of Fatih Sultan Mehmed, as also seen in Istanbul and the rest of Greece. 
- The present-day Serres bedesten is not the original structure described by Evliyâ Çelebi, based on his text itself. The now standing building represents a later construction phase dating to the years after the fire of 1718 .

- This study corrected the misdating of the Larissa bedesten by previous authors, and confirmed its construction before the year 889 AH/1484 CE. New archival evidence was published from the Arabic waqfiyeh of its founder Hac1 Ömer Bey the son of Hac1 Turhan. 


\section{REFERENCES}

1. $\quad$ Ak (Mahmut), Aşık Mehmed Menazırü'l-Avalim, 3 Vols., Ankara 2007.

2. Akar (Tuba), "Osmanlı Kentinde Ticari Mekânlar: Bedesten-Han-Arasta-Carș1 Mekânları Literatür Değerlendirmesi," Türkiye Araştırmaları Literatür Dergisi - Türk Mimarlık Tarihi, Cilt 7, Say1 13 (2009), 267-292.

3. Akozan (Feridun), "İstanbul'un Kapalı Çarşısı". Tarih Dergisi 32 (1979), pp. 759770 ,

4. $\quad$ Aktepe (M. Münir), "Çandarli. XIV. yüzyılın ilk yarısında Osmanlı hânedanı ile birlikte ortaya çıkan ve Osmanlı Devleti'nin gelişmesinde rol oynayan bir Türk ailesi," TDV İslâm Ansiklopedisi Vol. 9 (1993), pp. 209-211.

5. Aktepe (Münir), Şem'dânîzâde Fındıklılı Süleyman Efendi Tarihi: Mür 'it't-Tevârih, Cilt 1, İstanbul: Edebiyat Fakültesi Matbaasi, 1976.

6. Alfayrūzābādey (Mohamed bin Ya'qūb), alqāmūs almuhịt (in Arabic= The overall dictionary), al'erqsosī (Mohamed N.) (Ed.), Damasucs, 1998. URL: https://archive.org/details/WAQ105905_201402/page/n3/mode/2up [Access Date: Feb. 11, 2020]

7. Al-Rīhāwī (Abdel-Qāder), "khānāt madinet Dimashq" (in Arabic= The Khans of Damascus), Annual Archaeological Arabic Syrian, Vol. 25 (1975), 1/2, pp. 47-82.

8. Ameen (Ahmed), Islamic architecture in Greece: Mosques, Alexandria: Bibliotheca Alexandrina, 2017.

9. Ameen (Ahmed), "Ottoman use of the existing public buildings in former Byzantine towns: Greece as case study", Proceedings of the 15th International Congress of Turkish Art, Michele Bernardini and Alessandro Taddei with the collaboration of Michael Douglas Sheridan (Eds.), Naples, Università di Napoli "L’Orientale" 16-18 September 2015, Ankara 2018, pp. 89-107.

10. Ameen (Ahmed), "The Ottoman architecture in Greece then and now: quantitative method," SHEDET, 6 (2019) pp. 93-115, Doi.10.36816/shedet.006.06

11. Ameen (Ahmed), "Bilingual and trilingual inscriptions of the Ottoman buildings," Abgadiyat, scientific refereed annual journal, Calligraphy Center - Bibliotheca Alexandrina, 14 (2019).

12. Ayverdi (Ekrem Hakkı), İstanbul Mimari Çağının Menşei - Osmanlı Mimarisinin İlk Devri 630-805(1230-1402), İstanbul Fetih Cemiyeti, İstanbul Enstitüsü, No. 57, İstanbul, 1972.

13. Ayverdi (Ekrem Hakkı) and Aydin (Yuksel I.), Ilk 250 senenin Osmanli mimarisi, Istanbul: Istanbul Fetih Cemiyeti, 1976, Istanbul,

14. Ayverdi (Ekrem Hakk1), Avrupa'da Osmanli Mimari Eserleri, IV. Bulgaristan, Yunanistan, Arnavutluk, Istanbul: Fetih Cemiyeti Yayınları 1982.

15. Barkan (Ömer Lütfi) - Ayverdi (Ekrem Hakk1), İstanbul Vakıfları Tahrir Defteri 953 (1546) Târîhli, İstanbul: İstanbul Fetih Cemiyeti, 1970, no.2045.

16. Baş (Ali) - Bozkurt (Tolga), "Konya Bedesteni," Selçuk Üniversitesi Sosyal Bilimler Enstitüsü Dergisi, Y11 2003, Say1 10, pp. 493-506.

17. Çam (Nusret), "Arasta. آراسته Ustü genellikle tonoz veya çatıyla örtülü bir sokağın iki yanında karşılıklı sıralanan ve aynı cins malları satan dükkânların meydana getirdiği çarşı," TDV İslâm Ansiklopedisi 3 (1991), pp. 335-336.

18. Çayci (Ahmet), Eşrefoğlu Beyliği Dönemi Mimari Eserleri, Türk Tarih Kurumu Yayinlari, Ankara, 2008.

19. Çetinaslan (Mustafa), "Taş Vakfiyeler ve Beyşehir Eşrefoğlu Camii'nin Taş Vakfiyesi," in: Eşrefoğulları Beyliği: Uluslararası Orta Anadolu ve Akdeniz Beylikleri Tarihi, Kültürü ve Medeniyeti Seтроzуuти I,

20. Cezar (Mustafa), Typical Commercial Buildings of the Ottoman Classical Period and the Ottoman Construction System, Istanbul 1983.

21. Dalsar (Fahri), Bursa'da Ípekçilik, İstanbul: İ.Ü İktisat Fakültesi, 1960,

22. Delilbasi (Melek), "The Via Egnatia and Selânik (Thessalonica) in the 16th century," in: Via Egnatia under Ottoman rule (1380-1699), Series: Halcyon Days in Crete, Vol. 2: A Symposium Held in Rethymnon, 9-11 January 1994, E. Zachariadou (ed.), Rethymnon:

Crete University Press, 1996, pp. 67-84.

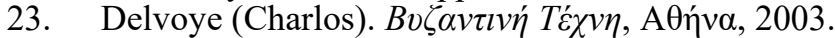

24. Doğan (Cabir), "Fethinden Kaybına Rodos (1522-1912)," Journal of Social Sciences, SDU Faculty of Arts and Sciences, December 2013, No:30, pp..67-88.

25. Elhaddad, (M. H.) Al-'ma'ra al-islamia fi Oroupa al-'Othmania. Kuwait, 2002. 
26. Eren (Halit), Oğuz (Mustafa) and Mete (Zekai), Balkanlar'da Osmanlı vakıfları, vakfiyeler Yunanistan, 5 Vols., İstanbul: IRCICA, 2017.

27. Ergin (Osman Nuri), "Bedestan", İslam Ansiklopedisi, İslâm Âlemi Tarih, Coğrafya, Etnografya ve Biyografya Lugatı, c.2, İstanbul, 1979, pp. 440-442

28. Eryavuz (Şebnem), "Kervansaray. Kervanların güvenliği ve konaklaması için anayol kenarında tesis edilen vakıf yapı," TDV İslâm Ansiklopedisi 25 (2002), pp. 299-302.

29. Evliyâ \#1: Evliyâ Çelebi, Seyahatname, Autograph manuscript, Bağdat köşkü 308, Book 8;

30. Evliyâ \#2: Evliyâ Çelebi, Seyahatnâmesi .vol. 8 (İstanbul :Orhaniye Matbaasi, 1928);

31. Evliyâ \#3: Evliyâ Çelebi (bin Derviş Mehemmed Zilli), Evliyâ Çelebi Seyahatnamesi

VIII. Kitap, [Topkapı Sarayı Kutuphanesi Bağdat 308 numaralı yazmanın transkripsiyonudizini], edited by Kahraman (Seyit Ali), Dağlı (Yücel) and Dankoff (Robert), (İstanbul: Yapı Kredi Yayınları, 2003);

32. Evliyâ \#4: Günümüz Türkçesiyle Evliya Çelebi Seyahatnamesi 5. Kitap 2 Cilt Akkirman - Belgrad - Gelibolu - Manastır - Özü - Saraybosna - Slovenya - Tokat - Üsküp, 5. kitap, 2. Cilt, haz. Kahraman (Seyit Ali), (İstanbul: Yap1 Kredi, 2010);

33. Evliyâ \#5: Günümüz Türkçesiyle Evliyâ Çelebi seyahatnâmesi: Gümülcine, Kavala, Selânik, Tirhala, Atina, Mora, Navarin, Girit Adast, Hanya, Kandiye, Elbasan, Ohri, Tekirdă̆l, 8. kitap, 2 Cilt, haz. Kahraman (Seyit Ali), (İstanbul: Yap1 Kredi, 2011);

34. Evliyâ \#6: Günümüz Türkçesiyle Evliyâ Çelebi seyahatnâmesi: Kütahya, Manisa, İmir, Antalya, Karaman, Adana, Halep, Şam, Kudüs, Mekke, Medine, 9. kitap, 2. Cilt, haz. Kahraman (Seyit Ali), (İstanbul: Yap1 Kredi, 2011).

35. Evliyâ \#7: Evliyâ Çelebi (bin Derviş Mehemmed Zilli), Evliyâ Çelebi Seyahatnamesi 10. Kitap, [Istanbul Universitesi Kütüphanesi Türkçe Yazmalar 5973, Süleymaniye Kütüphanesi Pertev Paşa 462, Süleymaniye Kütüphanesi Hacı Beşir Ağa 452 Numaralı Yazmalrın Transkripsiyonu-Dizini], edited by Kahraman (Seyit Ali), Dağlı (Yücel) and Dankoff (Robert), İstanbul: Yapı Kredi Yayınları, 2007.

36. Evliyâ \#8: Evliyâ Çelebi, Günümüz Türkçesiyle Evliyâ Çelebi Seyahatnâmesi: Istanbul, 1. Cilt, 2. Kitap, haz.: S. A. Kahraman - Y. Dağlı, İstanbul: Yapı Kredi Yayınları, 2003.

37. Eyice (Semavi), "Bedesten. Osmanlı dönemi Türk şehirlerinde ticaret bölgesinin çarş1 içindeki merkezi ve değerli malların saklanıp satıldığı bir bina türü," TDV Islâm Ansiklopedisi 5 (1992), pp. 302-311.

38. Gökbilgin (M. Tayyib), XV - XVI Asirlarda Edirne Ve Paşa Livasi Vakiflar Mülkler Mukataalar, I. Ü. Edebiyat Fakültesi Yayınlarından No. 508, İstanbul 1952.

39. Göyünç (Nejat) and Özbilgen (Erol), Eski Malatya'da Silâhdar Mustafa Paşa Hanı ve Han'ın restitüsyonu hakkında, Tarih Enstitüsü Dergisi Sayı 1'den ayrıbasım, İstanbul, 1970.

40. Halaçoğlu (Yusuf), "DELLÂL. دلآل. Bir haberi çarş1 pazar dolaşıp bağırarak halka duyuran veya satılacak bir malın alım satımında vasıta olup pazarlığı sonuçlandıran kimse," TDV İslâm Ansiklopedisi cilt 9 (1994), pp. 145-146.

41. Halaçoğlu (Yusuf), "Teselya Yenişehirli ve Türk Eserleri Hakkında Bir Araştırma," Güneydoğu Avrupa Araştırmalarl Dergisi 2/3 (1974), pp. 89-100

42. Hasab-Allah (Aya), 'ma'er Ghazi Khesro Bek al-baqiyeh bimadinet Saraiavo: diraset athariyeh memarieh wa faniyeh moqaranah (in Arabic $=$ The existing buildings of the Gazi Husrev-beg in Sarajevo: Archaeological, architectural and artistic comparative study), Master thesis, Faculty of Archaeology, Cairo University, 2016.

43. Inalcik (Halil) and Quataert (Donald), An Economic and Social History of the Ottoman Empire, vol. 1, 1300-1600, Cambridge University Press, 1997.

44. Inalcik (Halil), “Ístanbul'un Incisi: Bedesten,” in: Iktisat ve Din, Mustafa Özel (ed.), İstanbul, 1997, pp. 119-135,

45. Inalcik (Halil), "The Hub of the city: the Bedestan of Istanbul," in: Studies in the Ottoman Social and Economic History, IX, London, Variorum Reprints, 1985, Ch. IX.

46. Kiel (Machiel) - Deriziotis (Lazaros), "The old bedesten of Larissa (Yenisehir) in restoration," in: Seventh International Congress of Turkish Art, Warsaw 1990, pp. 141-145.

47. Kiel (Machiel), "Observations on the History of Northern Greece during the Turkish Rule: Historical and Architectural Description of the Turkish Monuments of Komotini and Serres, their Place in the Development of Ottoman Turkish Architecture and their Present Condition", Balkan Studies 12/2, (1971), 429-444.

48. Kiel (Machiel), "Ottoman building activity along the Via Egnatia: The cases of Pazargah, Kavala and Ferecik," in: Via Egnatia under Ottoman rule (1380-1699), Series: Halcyon Days in Crete, Vol. 2: A Symposium Held in Rethymnon, 9-11 January 1994, E. Zachariadou (ed.), Rethymnon: Crete University Press, 1996, pp. 149-155.

- 143 - The Ottoman bedestens in Greece 
49. Kiel (Machiel), "The Oldest Monuments of Ottoman-Turkish Architecture in the Balkans: The Imaret and the Mosque of Ghazi, Evrenos Bey in Giimiilcine (Komotini) and the Evrenos Bey Khan in the Village of Ilica Loutra in Greek Thrace (1370-1390)," in: Sanat Tarihi Yilliğg- Kunsthistorische Forschungen 12, Istanbul 1983, 117-144, pp. 133138.

50. Kiel (Machiel), "Yenice-i Vardar (Vardar Yenicesi Giannitsa): A Forgotten Turkish Cultural Center in Macedonia of the $15^{\text {th }}$ and $16^{\text {th }}$ Century," in: Studies on the Ottoman Architecture of the Balkans. London: Variorum, 1990, Ch. III.

51. Krautheimer (R.), Early Christian and Byzantine Architecture, Pelican History of Art 24, Baltimore: Penguin Books, 1965.

52. Kreiser (KLAUS), "Bedesten-Bauten im Osmanischen Reich", Istanbuler Mitteilungen 29 (1979), Tübingen, pp. 367-400,

53. Kuban (Doğan), Osmanlı Mimarisi, Fotoğraflar: Cemal Emden, YEM Yayın: 134, İstanbul 2007.

54. Lowry (Heath), The Shaping of the Ottoman Balkans 1550-1350: the Conquest, Settlement \& Infrastructural Development of Northern Greece, Istanbul, Bahçeşehir Univ. Publications, 2008.

55. Malaka (Mohamed A.), Al-monsha'āt al-tugāriyeh al-' othmāniyeh al-bāqieh bimadinet Istanbul ḥata 'awākher alqarn 12 Hijri/ 18 milādi, diraset athāriyeh memarieh wa faniyeh (in Arabic $=$ The existing commercial buildings in Istanbul ubtill the end of the $12^{\text {th }}$ $\mathrm{AH} / 18^{\text {th }}$ CE century: An Archaeological, architectural and artistic study), Master thesis, Faculty of Archaeology, Cairo University, 2016.

56. Mehmet Şeker, Ahmet Taşğın, Yakup Kaya, (Eds.), Türk Tarih Kurumu, Ankara 2018, pp. 219-251.

57. Millet (Gabriel), L'école grecque dans l'architecture byzantine, reprint (London, 1974).

58. Refik (Ahmet), Hicri On İkinci Asirda Hayati-İstanbul 1100-1200, İstanbul, 1930.

59. Sahillioğlu (Halil), "XVII. Asrın İlk Yarısında İstanbul'da Tedavüldeki Sikkelerin Râici," TTK Belgeler, Cilt 1, Say1 2 (Temmuz 1964), pp. 227-233.

60. Şemseddin (Sami Frashëri), Kamûs-ül Â'lâm. Tarih ve cografya lûgati ve tabir-i esahhiyle kâffe-yi esma-yi hassa-yi camidir , 6 Vols., Istanbul: Mihran 1889-1898.

61. Streck (M.), "Kaysāriyya", Encyclopedia of Islam, Second Edition, Edited by: P. Bearman, Th. Bianquis, C.E. Bosworth, E. van Donzel, W.P. Heinrichs, Leiden, Vol. IV (1997), pp. 840-841.

62. VGMA (=VAKIFLAR GENEL MÜDÜRLÜĞÜ ARȘivi), Defter nr. 743, s. 133-137, sira 29.

63. Yahya (Fou'ād), "Gard atharī li-khānāt madinet" (in Arabic= An archaeological inventory of the Damascene khans", Annual Archaeological Arabic Syrian, Vol. 31 (1981), pp. 67-105.

64. Yavuz (Muallim Memduh), Eşrefoğullari Tarihi Beyşehir Klavuzu, Konya: Babalik Matbaasi, 1934,

65. Yiğit (İsmail), "Ribât. الرباط Sinır boylarında ve stratejik mevkilerde askerî amaçlı müstahkem yapılara verilen ad," TDV İslâm Ansiklopedisi 35 (2008), pp. 76-79.

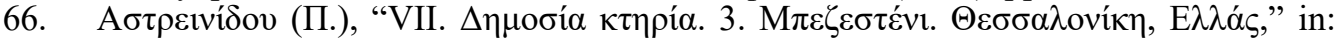

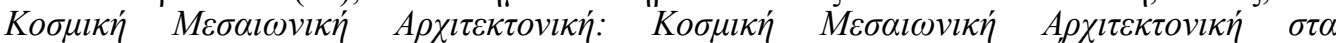

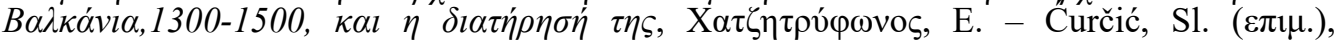

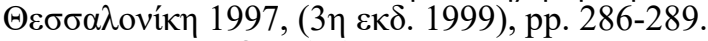

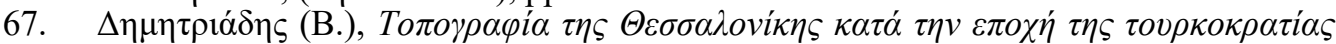

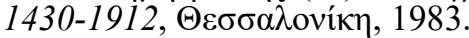

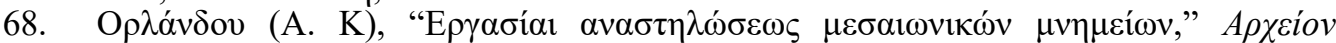

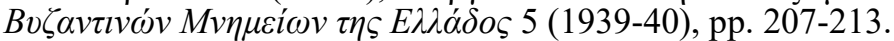

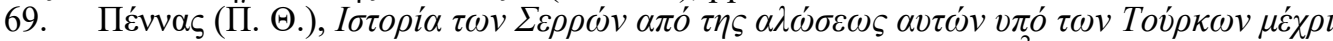

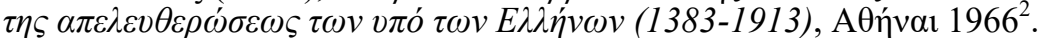

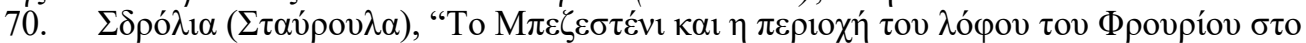

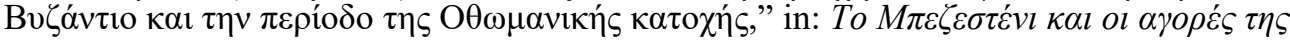

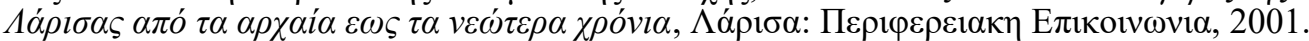

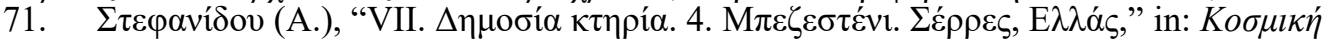

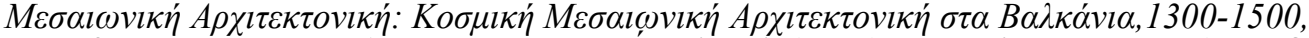

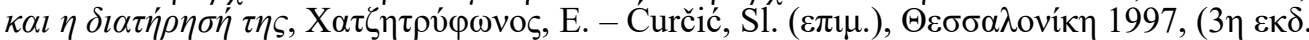
1999), pp. 290-293.

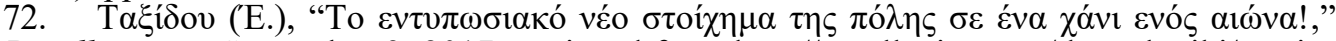
Parallaximag, September 3, 2017, retrieved from http://parallaximag.gr/thessaloniki/to-pioentyposiako-neo-stoichima-tis-polis-se-ena-chani-enos-aiona [Access Date: July. 12, 2018]. 